\title{
Voluntary Disclosure and Firm Visibility: Evidence from Firms Pursuing an Initial Public Offering
}

\author{
Draft: August 2018 \\ Comments welcome
}

\begin{abstract}
Drawing on predictions by Merton (1987) regarding the benefits to firms of enhancing visibility with prospective investors, we develop hypotheses for the role of pre-prospectus voluntary disclosure activities in terms of press releases and attendance at investor and industry conferences by firms pursuing an initial public offering (IPO). For a sample of IPOs during 2004-2014 we find that press release disclosures and conference attendance are common pre-IPO disclosure strategies. Tests using the passage of the 2005 Securities Offering Reform as a source of quasi-exogenous variation in preprospectus disclosures reveal, consistent with Merton (1987), that disclosures in this regime appear designed to enhance firm visibility, but have little effect on the extent of adverse selection costs. Overall, our evidence suggests that pre-IPO voluntary disclosure strategies provide benefits to newly public firms beyond mitigating informational asymmetries.
\end{abstract}

JEL: M4, G14, G32

Keywords: voluntary disclosure; press releases; investor conferences; visibility; initial public offering; underpricing 


\section{Introduction}

Merton (1987) argues that before investors can process detailed information about a firm designed to alleviate information asymmetry (such as regulated financial information in an annual report), investors must first incur a cost to become aware of the firm. In Merton's (1987) model, "visibility" (i.e., increased investor awareness) drives additional interest in the stock by lowering setup costs for potential investors, thereby shifting the demand curve outward. With a lack of prior regulatory financial reports and an absence of coverage by information intermediaries (e.g., analysts), firms contemplating an initial public offering (IPO) face both a lack of visibility and elevated information asymmetry. To address these issues, firms pursuing an IPO can voluntarily disclose information. While prior studies document a negative association between proxies for information asymmetry and the amount of disclosure provided in the IPO prospectus (see, e.g., Leone et al., 2007; Guo et al., 2004; Barth et al., 2017; Boone et al., 2016), relatively little research examines a visibility-enhancing role for pre-IPO disclosures.

In this study, we focus on two forms of voluntary disclosure activities made by firms prior to filing any detailed regulatory information and the related IPO roadshow: firm-initiated press releases and attendance at investor and industry conferences. The existence of these pre-prospectus voluntary disclosure activities are recognized in the Securities Act of 1933 and its subsequent modifications. Broadly, regulations surrounding an IPO seek to impose liability on firms that solicit interest and/or make offers of securities prior to filing a regulated prospectus with the Securities and Exchange Commission (SEC), with violations of these restrictions referred to as "gun jumping" (SEC, 2005). While firms are permitted to engage in pre-prospectus disclosures that do not make these types of offers, no empirical study that we are aware of examines the presence or use of these disclosures by firms pursuing an IPO. Our study seeks to fill this gap. 
We consider two (non-mutually exclusive) roles for pre-prospectus disclosures in the IPO process: enhancing firm visibility with prospective investors and/or reducing adverse selection costs by mitigating informational asymmetries. Despite a theoretical distinction by Merton (1987, p.501) between "advertising about the firm that is targeted for investors" to enhance visibility and disclosures that "provide substantive information" capable of reducing information asymmetry, any given disclosure may empirically target both roles. While this makes distinguishing the visibilityenhancing and information asymmetry roles for pre-prospectus disclosures difficult empirically, we use Merton's model to develop hypotheses that distinguish between the use of pre-IPO prospectus disclosures by firms pursuing an IPO to enhance their visibility and the alternative (non-mutually exclusive) goal of mitigating informational asymmetry with prospective investors. ${ }^{1}$

For a sample of 569 IPOs from January 2004 - July 2014, we find that press releases and conference attendance are common pre-prospectus disclosure strategies. The median firm pursing an IPO issues two press releases and $16.7 \%$ of firms attend an investor conference in the year before the issuance of a prospectus. Consistent with press release disclosures focusing on enhancing visibility, most press releases are short (less than a page) and predominantly product-related (36\%). However, the determinants of pre-prospectus disclosure suggest a role for both visibility-enhancement and information asymmetry as factors in the decision to disclose. Specifically, we find that the likelihood of attending a conference or issuing a press release in the pre-prospectus period is significantly correlated with the extent of factors associated with elevated information asymmetry, including heightened product market competition and operating in a high-technology industry, and with factors associated with the need for enhanced visibility including the extent of pre-IPO investment and the presence of information intermediaries such as venture capital backing.

\footnotetext{
${ }^{1}$ Notably, Li and You (2015) perform a similar exercise with analyst coverage in that they attempt to empirically separate whether analysts improve a firm's visibility or mitigate a firm's informational asymmetry.
} 
To distinguish between these alternative roles for pre-prospectus disclosure, we draw on the theoretical predictions by Merton (1987) to identify several IPO-related outcomes that should be associated with visibility-enhancing disclosures, in particular, (1) investor demand for regulated financial information; (2) investor demand for the firm's equity (as reflected in price changes); (3) the breadth of post-IPO equity ownership; and (4) post-IPO coverage by information intermediaries (e.g., analysts and financial press). Based on Merton's (1987) model, we expect that visibilityenhancing disclosures will lead to elevated investor demand for financial information, positive IPO price revisions, increased breadth of ownership, and higher post-IPO coverage by information intermediaries. To the extent that these forms of disclosure also (or primarily) serve to reduce information asymmetry, we expect disclosures will be associated with reduced IPO underpricing and lower bid-ask spreads in the post-IPO period, suggesting lower adverse selection costs.

Despite these predictions, the decision by firms to engage in pre-prospectus disclosure is endogenous. In particular, the associations with post-IPO outcomes that we observe may be due to the fundamentally different firms that choose to engage in pre-prospectus disclosure rather than due to the effects of the disclosure itself. As a result, we augment our identification strategy in two ways. First, we exploit a regulatory reform that affected firms' ability to engage in pre-prospectus visibilityenhancing disclosures. The December 2005 Securities Offering Reform (SOR) offers safe harbor for communications (both oral and written) by firms when made more than 30 days prior to filing a registration statement as long as the communications do not reference a securities offering. In contrast, the SOR continues to prohibit the disclosure of forward-looking information in the pre-IPO period. Thus, the SOR liberalizes firms' ability to make visibility-enhancing disclosures while holding constant the regulatory constraints on disclosures to address informational frictions, such as forward-looking earnings forecasts. Consistent with the SOR liberalizing firms' ability to engage in visibility-enhancing disclosures in a pre-prospectus period, we find that conference attendance and press release issuance are both more frequent in the post-SOR period. In addition, the content of such 
press releases shifts around the SOR in that firms reduce (increase) the proportion of earnings- and equity-related (product-related) press releases. Thus, the SOR helps us better separate the effects of visibility-enhancing disclosure activities on our IPO-related outcomes from the (non-mutually exclusive) alternative of voluntary disclosure to mitigate informational asymmetries. Second, to ensure that samples of disclosing and non-disclosing firms appear similar based on fundamental determinants of the decision to disclose, we use entropy balancing to reweight the control sample of non-disclosing firms in our regressions so that no significant differences exist in the means, variances, or skewness of any key disclosure determinants across the two samples. This form of matching on observables (i.e., entropy balancing) retains all control sample observations while limiting concerns with potentially noisy one-to-one matches (Hainmueller, 2012; McMullin and Schonberger, 2015). After entropy balancing, disclosing and non-disclosing samples display minimal differences in the distribution of determinants associated with the decision to disclose, aiding in our identification of the effect of the disclosures themselves separate from (correlated) fundamentals.

Our main findings are as follows. With regard to whether investors acquire detailed firm information in response to pre-prospectus disclosures, we find that investor search activity on the SEC's EDGAR site during the IPO filing period is positively related to the issuance of preprospectus press releases and conference attendance. The fact that this positive relation is concentrated in the post-SOR period is evidence that EDGAR search activity in the IPO filing window appears more sensitive to visibility-enhancing disclosures. Because the filing period includes the IPO roadshow, this evidence further suggests a complementary relation between pre-prospectus disclosures and subsequent information search by prospective investors surrounding the roadshow. In terms of whether shareholder demand for IPO shares is affected when firms provide more preprospectus voluntary disclosure, we find a positive association between IPO filing price revisions and pre-prospectus disclosure that is also more pronounced in the post-SOR period. For example, a onestandard deviation increase in press release issuance is associated with a filing period price increase 
of $4.3 \%$ in the post-SOR period. In further support of a visibility-enhancing role, we find a positive relation between measures of post-IPO coverage by information intermediaries and pre-prospectus disclosure. ${ }^{2}$ For example, a one-standard deviation increase in press release issuance is associated with an increase in analyst following of $13.5 \%$ (a predicted increase of .8 analysts relative to the median of six post-IPO analysts per firm) and a predicted increase in post-IPO media articles of $13.5 \%$, while attending at least one conference is associated with a $16.9 \%$ predicted increase in postIPO media coverage. Importantly, these results are also stronger subsequent to the SOR and are robust to the more stringent entropy balancing test specification. We also find some evidence that IPO firms' investor bases are more dispersed (with fewer concentrated holdings) in the presence of pre-prospectus disclosures.

While the empirical evidence thus far suggests a visibility role for pre-prospectus disclosures, we also explore whether these disclosures serve to mitigate adverse selection costs. First, with regard to IPO underpricing, we find a positive relation between underpricing and pre-prospectus disclosure (particularly for press releases), which is consistent with underpricing reflecting increased investor attention and/or a partial adjustment to investor demand by the underwriter (see, Hanley, 1993). This positive relation suggests that rather than mitigating the extent of adverse selection costs, disclosing firms leave money on the table in the form of underpricing. ${ }^{3}$ Second, we find no relation between pre-prospectus disclosures and either post-IPO bid-ask spreads or equity price volatility (during the 24-day quiet period), inconsistent with these disclosures reducing uncertainty for investors trading in the IPO firms' shares. Broadly, these tests provide empirical evidence consistent with Merton's

\footnotetext{
${ }^{2}$ Related research documents the importance of this post-IPO visibility. Mehran and Peristiani (2009) and Bharath and Dittmar (2010) find that IPO firms exit public markets when they fail to generate sufficient investor attention subsequent to their IPO.

${ }^{3}$ In additional tests, we find that firms with more pre-prospectus disclosures display greater wealth revaluations during the IPO process, consistent with recent research suggesting a role for prospect theory in IPO pricing (e.g., Loughran and Ritter, 2002; Willenborg et al., 2015).
} 
(1987, p.501) distinction between visibility-enhancing disclosures and disclosures that "provide substantive information" to investors.

We conduct additional validation tests for our main results. First, we rule out that the postIPO pricing effects and pre-IPO voluntary disclosure are merely artifacts of increased underwriter effort via due diligence or stock promotion (see, e.g., Hanley and Hoberg, 2010; Cook et al., 2006). Second, we rule out a "hype" explanation for our results by examining long-run post-IPO equity performance. Inconsistent with uninformed investors overpricing the IPO at the end of the first day of trading, we find no evidence of underperformance in the year following the offering for firms with more extensive pre-prospectus disclosure.

Our paper contributes to the IPO and disclosure literatures in several ways. First, in contrast to research on voluntary disclosure for seasoned firms (see Beyer et al., 2010), research on the disclosure strategies of private firms (that are going public) is far more limited. On this dimension, disclosure theories (and related studies on IPO disclosure) generally presume that investors are aware of a firm's existence (e.g., Verrecchia, 1983). This has led studies of firms pursuing an IPO to focus almost solely on the role that disclosure plays in mitigating adverse selection (see, e.g., Leone et al., 2007) subject to proprietary costs. ${ }^{4}$ Using Merton's (1987) model as a foundation, we add to this literature by documenting the need by some firms for pre-IPO visibility and its fundamental impact on their voluntary disclosure choices before they file their IPO prospectus. Second, we add to the literature on how firms can generate more attention when going public (such as lowering an IPO price, increasing issuance size, or hiring a prestigious underwriter, see, e.g., Demers and Lewellen, 2003; Dambra et al., 2018; Jeon et al., 2015). Our evidence suggests that firms can generate more attention when going public by modifying their pre-prospectus voluntary disclosure strategies. Third,

\footnotetext{
${ }^{4}$ For research that focuses on the role of proprietary costs in explaining disclosure patterns by newly public firms, see work by Boone et al. (2016); Schrand and Verrecchia (2005); Dambra et al. (2015); Hanley and Hoberg (2010); Loughran and McDonald (2013); Guo et al. (2004); Barth et al. (2017); Brown et al. (2018); Feng et al. (2018).
} 
our study sheds light on the economic consequences of pre-IPO voluntary disclosures following the 2005 SOR. While some stakeholders expressed concern that by removing restrictions on disclosure, the SOR would incent firms to "hype" their stock prior to raising capital (e.g., Lang and Lundholm, 2000), the evidence based on firms pursuing seasoned equity offerings suggests that firms making voluntary disclosures experience reduced information asymmetry in the post-SOR regime (see, e.g., Shroff et al., 2013; Clinton et al., 2014). In contrast to this evidence for seasoned issuers, we find no evidence that managers at firms pursuing an IPO use post-SOR disclosures to mitigate adverse selection costs. We interpret this as evidence that IPO firms' ability to disclose in a less-regulated setting appears better suited to improve visibility, which itself is an economic benefit for firms going public (see Lowry et al., 2017).

The remainder of the paper is organized as follows. Section 2 discusses related research and uses Merton's (1987) model to develop the underpinnings for our hypotheses and tests. Section 3 discusses sample selection procedures and the research design. Section 4 provides descriptive statistics while Sections 5 and 6 report results. Section 7 concludes.

\section{Hypothesis Development}

\subsection{Merton's (1987) Model}

Merton (1987) models an equilibrium where investors possess incomplete information prior to making investment decisions and argues that before investors can process detailed information to mitigate asymmetric information problems, they must first be aware of the firm's existence. In Merton's model, investors face a fixed "set-up" cost inhibiting them from learning about all new securities. From a firm's perspective, it can therefore be optimal for managers to expend resources (i.e., issue disclosures) to make investors aware of the firm because the attention generated from new (previously unaware) investors will increase the investor base and the corresponding stock price. The result is a tradeoff for firms between the costs of disclosure and the benefits of visibility with prospective investors. In examining this tradeoff, the costs of visibility-enhancing disclosures are 
somewhat difficult to measure empirically as they stem from expenditures on the investor relations function and the use of management time to prepare and make disclosures. In our determinants models (discussed in detail in Section 3), we obtain proxies for variation in the sophistication of preIPO institutions as a proxy for expenditures on the investor relations function. In contrast, we can observe variation in the outcomes of visibility-enhancing disclosures more directly. These outcomes form the basis of our predictions following from Merton's (1987) model in our IPO setting.

First, in settings where managers expend resources to engage in visibility-enhancing disclosures, the outcome should be increased investor acquisition and processing of detailed information about the firm. With regard to the detailed information in the IPO prospectus, prior studies find that prospectus disclosures mitigate informational frictions between issuers and prospective investors. ${ }^{5}$ The consistent conclusion reached is that there is a negative association between prospectus disclosure quality and informational asymmetry (measured via underpricing or other post-IPO measures of market liquidity). We extend these studies by focusing on the effect of pre-prospectus voluntary disclosures on investors' subsequent acquisition of detailed information, which we measure via downloads from the Securities and Exchange Commission's (SEC's) EDGAR site during the prospectus filing period that includes the IPO roadshow. In essence, our first hypothesis (in null form) considers the relation between pre-prospectus disclosure and the acquisition of more detailed disclosures that are the focus of prior research examining shifts in information asymmetry around the IPO:

\section{H1: Pre-prospectus voluntary disclosure has no effect on investor's acquisition and processing of detailed firm information available in regulatory filings.}

\footnotetext{
${ }^{5}$ For instance, Leone et al. (2007) analyze the "Use of Proceeds" disclosure in the IPO prospectus, while Hanley and Hoberg (2010), Loughran and McDonald (2013), Brown et al. (2017), Guo et al. (2014), Barth et al. (2017), Chaplinsky et al. (2017), and Boone et al. (2016) either hand-collect data or use textual analysis to measure the "quality" of IPO prospectus disclosure.
} 
If firms pursue visibility-enhancing pre-prospectus disclosures, Merton's model implies they should experience an upward shift in the demand for their shares (with a corresponding increase in price) as a result of more investors willing to incur the lowered setup cost to become aware of the firm. We predict that this effect will manifest in both the pricing and ownership of the IPO. In terms of pricing, we predict a positive relation between visibility-enhancing pre-prospectus disclosures and filing price revisions. This prediction is motivated by visibility-enhancing pre-prospectus disclosures stimulating excess demand from institutional investors during the IPO book-building process. That said, in the presence of underwriters with incentives for a lower initial filing price range prior to a road show (see Loughran and Ritter, 2002; Willenborg et al., 2015) the predicted price improvement implied by Merton (1987) may not be fully incorporated in the initial IPO valuation. Consistent with this idea, some studies find that only a portion of the positive information obtained during the bookbuilding period gets into the offer price (see, Hanley, 1993). Any such partial adjustment would lead to a positive prediction between pre-prospectus disclosure and first-day returns. Alternatively, if visibility-enhancing pre-prospectus disclosures predominantly influence retail investors' setup costs, we would expect a similar relation with first-day underpricing as retail investors are largely unable to participate in the book-building process and are typically restricted in the allocation of IPO shares. In contrast to this prediction for a positive relation with underpricing, if pre-prospectus disclosures primarily serve to mitigate adverse selection costs then we should find lower (rather than higher) underpricing for firms engaging in more voluntary disclosure. This discussion leads to our pricing hypothesis (in null form):

\section{H2: Pre-prospectus voluntary disclosure has no effect on IPO pricing.}

Beyond the pricing effects of pre-prospectus disclosure discussed above are the implications of that disclosure on firm ownership post-IPO. Based on Merton's (1987) model, we expect that firms pursuing visibility-enhancing pre-prospectus disclosures will exhibit more dispersed ownership. In particular, we expect smaller average ownership stakes and fewer concentrated stakes 
by investors. In line with this, prior IPO literature emphasizes that one of the key benefits to going public is obtaining access to a diversified shareholder base (e.g., Chemmanur and Fulghieri, 1999; Lowry et al., 2017). This discussion leads to our third hypothesis (in null form):

\section{H3: Pre-prospectus voluntary disclosure has no effect on ownership dispersion following the IPO.}

If in fact pre-prospectus voluntary disclosure enhances investor attention, the firm should also obtain benefits from enhanced visibility such as higher post-IPO analyst coverage and media attention (see, e.g., Mehran and Peristiani, 2010; Liu et al., 2014; Li and You, 2015). For example, Liu and Ritter (2011) emphasize the importance of non-price dimensions of the IPO process such as generating sufficient analyst coverage. Our fourth hypothesis is (in null form):

\section{H4: Pre-prospectus voluntary disclosure has no effect on coverage of the firm by analysts and the financial press following the IPO.}

As noted above, a key aspect of Merton's model to our setting is that it distinguishes between visibility-enhancing disclosures and disclosures designed to mitigate information asymmetry. In specific, Merton (1987, p.501) states that "Although not mutually exclusive, the techniques used and resources expended by the firm to expand its investor base are logically separable from those used to provide substantive information that existing shareholders can use to evaluate their portfolio position in the firm." Consistent with a distinction between the potential effects of pre-prospectus voluntary disclosures increasing visibility, we expect that visibility-enhancing pre-prospectus disclosures will be largely unrelated to measures of information asymmetry in the post-IPO period. Evidence in favor of this distinction between visibility-enhancing and information asymmetry roles for disclosure parallels a distinction made by Li and You (2015) in their examination of the effect of analyst coverage changes for seasoned firms.

However, whether pre-prospectus disclosures can ameliorate asymmetric information problems similar to that of the detailed prospectus (e.g., Leone et al. 2007) is an unanswered empirical question. We test this prediction in our IPO setting by examining the information 
asymmetry reflected in average daily bid-ask spreads and equity price volatility during the 24-day quiet period following the start of IPO trading (Guo, Lev, and Zhou, 2004; Schrand and Verrecchia, 2005). Our final hypothesis is (in null form):

\section{H5: Pre-prospectus voluntary disclosure has no effect on the informational asymmetry in the immediate post-IPO period.}

\section{Sample Selection, Research Design, and Identification Strategy}

\subsection{Sample selection}

We obtain a sample of IPOs by U.S. firms from the Securities Data Corporation (SDC) New Issues database with initial filing dates on or after January 1, 2004 and a successful offering completed on or before July 28, 2014. This period aligns with detailed coverage of press releases and media articles via Ravenpack data available to us (see below). On this sample, we impose the following filters: 1) we include IPO firms issuing common stock (without warrants attached, see Barth et al., 2017); 2) we exclude closed-end funds, open-end funds, real estate investment trusts, American Depository Receipts, rights offerings, limited partnerships, and special purpose vehicles (which excludes SIC codes 6091, 6371, 6722, 6726, 6732, 6733, and 6799); 3) we exclude IPO firms already registered with the SEC at the time of the IPO, namely, firms with 10-K/Q or 8-K filings more than 3-months prior to the IPO date (see Cedergren, 2014); and 4) we exclude firms that are spin-offs, firms going IPO after a leveraged buyout, firms with wholly-owned subsidiaries that are publicly-traded, or privatizations. Unlike the IPO firms in which we are interested, all of the firms in filters (3) and (4) have prior experience with the disclosures required by public equity markets. Firms passing these filters must have data available on CRSP and COMPUSTAT (to calculate underpricing, etc.); firm age on Jay Ritter's site (https://site.warrington.ufl.edu/ritter/ipo-data/); and post-IPO institutional ownership available on Thompson Reuters. To isolate firms with visibility needs, we delete 40 firms that have full article media coverage by Dow Jones media sources in the one to two years prior to their filing of an IPO prospectus (this filter excludes high-profile IPOs with little need 
to create additional visibility, including Facebook, Alphabet [Google], Tesla, Twitter, and LinkedIn). ${ }^{6}$ Last, we delete observations in the top and bottom one percent of the distributions of return on assets and pre-IPO new financing to eliminate outliers. ${ }^{7}$ These filters and requirements leave us with a sample of 569 IPOs. Table 1, Panel A summarizes these sample selection procedures.

\subsection{Research design}

To test our hypotheses related to pre-prospectus voluntary disclosure activities and IPO outcomes, we estimate the following regression using ordinary least squares (OLS) or a negative binomial model (for dependent variables that are counts following the recommendation by Rock et al., 2000) for each of the dependent (IPO outcome) variables used to test our hypotheses: ${ }^{8}$

$$
\begin{aligned}
& {[\text { IPO Outcome }]=\beta_{0}+\beta_{1}[\text { Pre-Prospectus Disclosure }]+\beta_{2} \text { DualClass }+\beta_{3} L o g_{-} A T+} \\
& \beta_{4} \text { Log_REVT }+\beta_{5} R O A+\beta_{6} \text { RDAD_Exp }+\beta_{7} \text { Log_Age }+\beta_{8} V C+\beta_{9} \text { Big } 4+ \\
& \beta_{10} \text { ProdMktFluid }+\beta_{11} \text { New_FIN }+\beta_{12} \text { TopUW }+\beta_{13} \text { NasdaqRET_90 }+ \\
& \beta_{14} \text { IPOCount_90 }+\beta_{15} \text { HiTech_NonBio }+\beta_{16} \text { HiTech_Bio }+\beta_{17} \text { Bank }+ \\
& \beta_{18} \text { ExCh_NYSE }+\psi+\varepsilon
\end{aligned}
$$

\subsubsection{IPO outcomes}

To start, we describe the five sets of outcomes that we use to investigate the hypothesized benefits to pursuing visibility-enhancing disclosures under Merton's (1987) model. To measure the acquisition of detailed firm information by prospective investors, we utilize the SEC's EDGAR log file which contains the timestamp and IP address associated with documents accessed on EDGAR. In our setting, the primary document available in the pre-IPO period is the prospectus. $\log _{-} E D G A R$ is the natural $\log$ of the total document retrievals for each firm during the filing period up to the date of the IPO. ${ }^{9}$ We measure the pricing of IPO firms using filing price revisions (Revision) and first-day

\footnotetext{
${ }^{6}$ Unreported robustness tests reveal that our results are largely unaffected by the exclusion of these firms.

${ }^{7}$ Using robust regression to address potential influential observations (see Leone et al., 2018) leads to similar inferences (results untabulated).

${ }^{8}$ For a complete description of all variables used in our empirical analysis refer to Appendix A.

${ }^{9}$ We follow Drake et al. (2015) and eliminate IP addresses that likely reflect automated data retrieval services, namely IP addresses that access more than 5 documents in any one minute period or more than 1,000 documents in a given day. For a list of daily EDGAR log files see: https://www.sec.gov/dera/data/edgar-log-file-data-set.html.
} 
equity price changes (Underpricing). Revision measures the percentage change from the mid-point of the initial filing price range in the prospectus to the final IPO offer price. Underpricing measures the percentage change from the IPO offer price to the first-day closing price. If visibility stimulates investor demand for the firm's equity, then pre-prospectus disclosure will be positively associated with price revisions during the book-building period as well as with first-day underpricing (in the latter case, to the extent that price adjustments are partial and/or that visibility improves for retail investors). Alternatively, if asymmetric information is primarily mitigated through increased preprospectus disclosure then we should expect to find a negative association between Underpricing and our pre-prospectus disclosure proxies.

Because Merton's (1987) model implies more dispersed ownership for more visible firms, we investigate the number of institutional owners holding concentrated stakes as measured by holdings in excess of one percent of the post-IPO equity (Num_InstOwn>1\%) and the average size of an institutional owner's stake (Avg_IOStake) measured as the percentage of institutional ownership divided by the number of owners listed on the Thomson Reuters database for the first ownership reporting date following the IPO. We expect fewer concentrated holdings and smaller average stakes for firms with more visibility-enhancing disclosures, consistent with more dispersed ownership. Turning to coverage by information intermediaries in the post-IPO period, we measure analyst coverage (Analyst_Count) as the number of unique analysts issuing an EPS forecast for the firm in $I / B / E / S$ during the 12-month post-IPO period.

To measure coverage in the financial press we use the natural log of the number of Dow Jones news articles (Log_Media_1Y) about the firm in the 12-month post-IPO period. Finally, as noted above, Merton (1987) distinguishes between visibility-enhancing disclosures and disclosures designed to communicate substantive information regarding the firm's prospects. Based on this distinction, we should expect pre-prospectus disclosures to be largely unrelated to measures of information asymmetry. However, prior literature documents a negative association between a range 
of voluntary disclosures and informational asymmetry (see Beyer et al., 2010 for a review), suggesting a negative relation as an alternative. To examine this empirically, we approximate postIPO informational asymmetry using the daily average closing bid-ask spread (BA_SpreadlM) and the volatility of style-adjusted daily equity returns (STD_ARET1M) over the 24-day quiet period starting one day after the IPO offer date. ${ }^{10}$

\subsubsection{Pre-prospectus disclosure variables}

The variables used to test our hypotheses are the incidence of pre-prospectus voluntary disclosure activities measured as firm-initiated press releases and attendance at investor and industry conferences by private firms prior to an IPO. The press release variable $\left(\log _{-} P R\right)$ is the natural $\log$ of one plus the number of press releases issued by the firm in the 12-month period ending with the filing of its IPO prospectus. We obtain press releases from Ravenpack's Dow Jones and PR Editions. Each press release must have a relevance score of 100 (i.e., be directly about the firm) and a novelty score of 100 (i.e., the first instance of a press release). ${ }^{11}$ We measure firm attendance at investor and industry conferences via an indicator variable (IConf) set to one for IPO firms attending at least one investor conference in the 12-month period ending with the filing of their IPO prospectus (and zero otherwise). Conference attendance is identified from Bloomberg or Ravenpack. Specifically, we use Bloomberg's EVTS database beginning in 2003 for event types tagged as "Corporate Access", “Analyst Marketing”, or “TV/Conf/Pres. Conference”, which we augment with Ravenpack where the press release type is listed as "conference-participant". ${ }^{12}$

\footnotetext{
${ }^{10} \mathrm{We}$ focus on the quiet period to avoid differences in post-IPO disclosures because the quiet period is largely restricted to releases of mandatory financial information (see Cedergren, 2014).

${ }^{11}$ Ravenpack's process for adding coverage for a firm comprises two steps. First, Ravenpack adds a firm and begins covering press releases and articles for the firm from that date forward. Second, when Ravenpack releases a new version of its database, the data provider takes all entities added prior to the version date and back-fills all available press releases and articles for each added firm. Because IPO firms are typically added as of the IPO's offering date, this back-filling feature is necessary for us to observe pre-prospectus press releases. As a result, we end our sample with the date of Ravenpack's most recent back-filling for version 4.0, which is July 28, 2014.

${ }^{12}$ We also exclude press releases of the type "conference-organizer" because these stem from brokerage houses announcing each of the firms attending that brokerage's conference, resulting in essentially duplicate press releases.
} 


\subsubsection{Disclosure determinants and control variables}

In our determinants models for the decision to engage in pre-prospectus disclosures, we seek to capture variation in the costs and benefits of issuing visibility-enhancing disclosures across firms. We draw on the IPO, voluntary disclosure, and visibility literatures for these determinants. We include issuer characteristics by including firm size ( $\log _{-} A T$ and $\left.\log _{-} R E V T\right)$, age (Log_Age), dualclass share holdings (DualClass), profitability (ROA), and research and advertising intensity (RDAD_Exp), which have been shown to affect post-IPO outcomes, the need for visibility, and the propensity to engage in voluntary disclosure (see e.g., Green et al., 2014; Chemmanur and Yan, 2009; Loughran and Ritter, 2004; Jones, 2007; Smart and Zutter, 2003; Kasznik and Lev, 1995). Next, we control for the presence of information intermediaries ( $V C$ and Big4) which play an important role in the certification of newly public firms (see Field, 1995; Brav and Gompers, 1997; Weber and Willenborg, 2003). In addition, we expect the presence of these institutions to be correlated with firms' sophistication in terms of the investor relations function. To the extent that the investor relations' department determines the amount of visibility-enhancing disclosure issued by firms, we expect that firms lacking VC-backing and a Big 4 auditor will face constraints on issuing pre-prospectus disclosures. Relatedly, we expect that firms with elevated proprietary costs will garner relatively greater visibility benefits from pre-prospectus disclosures, as these firms face competitive constraints in their prospectus disclosures. Consistent with this, the IPO disclosure literature argues that issuers make trade-offs between minimizing information asymmetry versus revealing competitive information through their proprietary disclosures (see Beyer et al., 2010). We follow Boone et al. (2016) and measure the extent of product market competition for IPO firms using the product market fluidity measure developed by Hoberg et al. (2014) for firms in the year of the IPO (ProdMktFluid, available from the Hoberg-Phillips data library: http://hobergphillips.usc.edu/). Following the argument by Merton (1987) that the benefits to visibility-enhancing disclosures will be greatest for firms with more extensive project investments, we control for the amount of new debt 
and/or equity capital raised in the pre-IPO period measured as a proportion of the book value of total assets $\left(N_{e w}\right.$ FIN). To control for the state of the IPO market, we include the value-weighted buyand-hold return to all NASDAQ stocks over the 90-day period ending one day prior to the offering date (NasdaqRET_90) along with the number of IPOs during this same 90-day period (IPOCount_90) (see, e.g., Lowry and Schwert, 2004; Chaplinsky et al., 2017). ${ }^{13}$

In our models for Num_InstOwn>1\%,Underpricing, and Log_Media_1Y, we include additional control variables. In specific, following Hanley, 1993) we augment our Underpricing regression by including Revision as an additional control variable in Equation (1). Following Cook et al. (2006) and Liu et al. (2014) we augment our Log_Media_1Y models by including filing-period financial press coverage (Log_Media_PreIPO) to control for underwriter due diligence in garnering media coverage during the filing period. In our Num_InstOwn>1\% negative binomial model, we include the percentage of institutional ownership (InstOwn) to isolate the variation in the count of concentrated holdings conditional on the total institutional ownership in the firm's post-IPO equity. Finally, to account for industry and time variation in post-IPO outcomes, we include separate industry indicators for bio-technology firms (HiTech_Bio), remaining high technology firms as identified by SDC (HiTech_NonBio), and financial services firms (Bank) along with year-fixed effects $(\psi)$ to account for the pre-SOR and post-JOBS period (which we separately examine via PreSOR and PostJOBS indicator variables in our determinants models, respectively).

\subsection{Identification strategy}

An implicit assumption underlying our hypotheses is that pre-prospectus disclosures affect subsequent IPO outcomes. However, Eq. (1) can only identify an association between IPO outcomes and pre-prospectus disclosure activities. To enhance our inferences, we use two approaches to aid in identifying a causal relation. First, we exploit a regulatory shock that affects firms' ability to provide

\footnotetext{
${ }^{13}$ In our Revision models, we include the value-weighted return to the NASDAQ index for the full filing period (NasdaqRET_File), rather than the return over the 90-day pre-IPO window.
} 
visibility-enhancing disclosures prior to issuing an IPO prospectus while holding constant firms' ability to use these same pre-prospectus disclosures to convey information with a primary goal of reducing information asymmetry (i.e., forward-looking information). Second, we employ entropy balancing to ensure similarity in key (observable) disclosure determinants across our treatment and control samples to aid in ruling out the effects of correlated fundamentals across the groups of disclosing and non-disclosing firms. Achieving covariate balance using entropy balancing further serves to rule out functional form misspecification as an alternative explanation for the relation between independent and dependent variables when using a multiple regression (Rosenbaum and Rubin, 1983; Shipman et al., 2017). We discuss each identification strategy in further detail below.

\subsubsection{The 2005 Securities Offering Reform (SOR)}

In December 2005, the SEC promulgated the Securities Offering Reform (SOR) to liberalize permitted disclosures prior to a securities offering. ${ }^{14}$ The SOR specifically outlined permitted communications in the period prior to filing a prospectus. For the purposes of our study, there are three provisions of the SOR that shift the disclosure landscape for IPO firms. First, the SOR permits communications (both oral and written) between issuers and prospective investors more than 30 days prior to filing a registration statement as long as such communications do not reference an upcoming security offering. Prior to the SOR, such communications ran the risk of litigation as "gun-jumping" violations. Second, the SOR permits disclosure of "regularly released factual business information" at any time to mitigate litigation risk. Third, the SOR defines the forms of written communication by issuers that must be publicly filed and disclosed to all prospective investors.

Of particular relevance to our setting is that under the SOR, direct oral communications, such as those occurring at investor conferences, are exempt from these latter public disclosure and filing requirements. In addition, the SOR continues to prohibit firms from providing forward-looking

\footnotetext{
${ }^{14}$ The final version of the SOR is available at: http://www.sec.gov/rules/final/33-8591fr.pdf.
} 
disclosures, such as earnings forecasts, which might otherwise serve to mitigate information asymmetry and from referencing a future offering if a formal prospectus is not yet issued. This is in stark contrast to the regulations for seasoned public firms, which are permitted to increase their use of forward-looking forecasts prior to a securities offering under the SOR regime. ${ }^{15}$ We exploit these provisions of the SOR and use its passage to identify the effect of visibility-enhancing disclosures on IPO pricing and post-IPO outcomes by estimating the following empirical model:

$$
\begin{aligned}
& {[I P O \text { Outcome }]=\beta_{0}+\beta_{1} I \operatorname{Conf}+\beta_{2} \log P R+\beta_{3} P r e S O R \times \log P R+} \\
& \quad \boldsymbol{\Sigma} \boldsymbol{\beta} \text { Controls }+\psi+\varepsilon
\end{aligned}
$$

The coefficients of interest in Eq. (2) are $\beta_{2}$, which captures the overall effect of preprospectus press releases activities and $\beta_{3}$, which identifies whether such disclosures have a differential impact prior to the passage of the SOR (with the main effect of the post-SOR variable reflected in the year fixed effects). To classify IPOs as pre-SOR, we require disclosures for 9 out of 12 months during the one-year pre-prospectus period to overlap with the period prior to the passage of the SOR. Thus, we classify IPOs with an initial SEC filing date on or before March 1, 2006 as preSOR IPOs (i.e., PreSOR $=1$ and 0 otherwise). In this way, controlling for annual time-fixed effects (and the remaining vector of control variables as detailed in Eq. [1]), we attempt to isolate the visibility-enhancing role of pre-prospectus disclosures and their differential effects on IPO-related outcomes following the passage of the SOR. ${ }^{16}$ Given the paucity of conference attendance prior to the SOR (see to Table 1), we are unable to identify an IConf and PreSOR interaction.

\subsubsection{Entropy Balancing}

If disclosing and non-disclosing firms differ fundamentally prior to the IPO, it becomes less clear whether pre-prospectus disclosures or those fundamentals are the cause of variation in visibility that we document. To address this concern, we employ entropy balancing (Hainmueller, 2012) as a

\footnotetext{
${ }^{15}$ Empirical evidence indicates that this SOR provision led to an increase in and more informative voluntary disclosure prior to seasoned equity offerings (see, Shroff et al., 2013; Clinton et al., 2014).

${ }^{16} \mathrm{We}$ also differentially analyze the information content of these press releases surrounding the SOR in Section 4.2.
} 
means to match firms with pre-prospectus disclosures to a control sample of IPO firms without such disclosures. Briefly, entropy balancing solves a constrained optimization in order to select weights for each observation in the control sample that equalizes the distributional moments (i.e., mean, variance, and skewness) between the treatment sample and the weighted control sample. The process stays as close as possible to having equal weights while avoiding using negative weights. The result is a weighted control sample that is indistinguishable (in distribution) from the treatment sample.

Because the size of our sample of 569 IPOs poses an issue when entropy balancing over all 17 control variables and 3 distribution moments, the first step in using entropy balancing is to understand the important determinants that are associated with the decision to engage in preprospectus voluntary disclosure. To do this we run an OLS (Logit) model where the dependent variable is the natural log of the count of pre-prospectus press releases, $\log _{-} P R$ (an indicator variable, IConf, set to one when issuers attend a conference prior to filing a prospectus and zero otherwise). We include the full slate of control variables listed in Eq. (1) since they have implications for a firm's ability to ameliorate informational asymmetries, to enhance investor recognition, and/or reflect the extent of any proprietary costs of disclosure.

Results of estimating these determinants models are presented in Table B.1 of Appendix B. In general, the determinants models show that the extent of press release disclosure is significantly associated with the degree of product market competition, the amount of firm sales (as a proxy for size), pre-IPO investment, the presence of venture capital funding and/or a Big 4 auditor, and operating in a high-technology industry. Similarly, the likelihood of attending a pre-prospectus conference is significantly related to the extent of product market competition, pre-IPO return on assets, the presence of a Big 4 audit firm, and operating in a high-technology industry. Evidence from the determinants models is consistent with firms relying on visibility-enhancing disclosure in the presence of elevated proprietary costs to regulated disclosures due to product market competition, which is in line with recent evidence on the importance of proprietary costs in predicting redactions 
in the IPO prospectus (Boone et al., 2016). The relation with a Big 4 audit firm and venture capitalist backing suggest that pre-IPO information intermediaries aid in certifying more extensive preprospectus disclosures.

Panels A and B of Table B.2 in Appendix B present summary statistics for covariate balance before and after entropy balancing on the key covariates identified by the determinants models. ${ }^{17}$ Consistent with the importance of these determinants, we find significant covariate imbalance on both means and variances before entropy balancing. After entropy balancing, standardized differences are near zero and variance ratios clustered around one, consistent with balanced covariates (Rubin, 2001). ${ }^{18}$ The success of our entropy balancing approach in achieving covariate balance leads us to use the control sample weights identified by this process in our subsequent tests to rule out the effects of correlated disclosure determinants along with addressing functional form misspecification in our multiple regression models examining the role of pre-prospectus disclosure in explaining variation in IPO outcome variables.

\section{Descriptive Statistics}

\subsection{Sample of IPOs}

Table 1, Panel B provides a frequency distribution of IPOs by year, along with corresponding distributions of the percent of IPO firms issuing press releases and attending investor conferences during the 12-month pre-prospectus period. Panel B shows that our sample of IPOs is not clustered in any particular year, although there is a marked increase over time in the likelihood of an IPO firm attending an investor conference in the pre-prospectus period. With regard to pre-prospectus press

\footnotetext{
${ }^{17}$ We use the match ratios reported in Table B.2 (discussed below) to verify that our entropy-balanced control samples do not assign large weights to a handful of control sample observations.

${ }^{18}$ As for any matched sample, the resulting estimate of the treatment effect is specific to the particular matched sample. In our setting, this means that tests relying on entropy-balanced control samples will not include both of our independent variables in the same model ( $\log _{-} P R$ and IConf) because each is used to determine the particular treatment and weighted control sample. In essence, under entropy balancing, matching is used in place of a multiple regression approach to control for the effect of the alternative disclosure channel.
} 
releases, the proportion of IPOs issuing press releases is above $50 \%$ in each year, with some evidence of an increasing trend over time. Panel A of Table 2 presents descriptive statistics on pre-prospectus disclosures and conference attendance. Pre-prospectus press release disclosures are present for $67.5 \%$ of the IPO firms where the log of the number of press releases issued in the pre-prospectus period $\left(\log _{-} P R\right)$ ranges from zero up to 4.06 (58 press releases), while $16.7 \%$ of firms attend an investor conference. Panel A also reports on the IPOs around the SEC's adoption of the Securities Offering Reform (SOR) on December 1, 2005 and with an offering date after the passage of the Jumpstart Our Business Startups (JOBS) Act on April 4, 2012. ${ }^{19}$ As noted in Section 3.3, we use passage of the SOR to identify the hypothesized benefits to pursuing visibility-enhancing disclosures. Approximately one-third of the IPOs in our sample occur in the pre-SOR period.

With regard to firm fundamentals, Panel B reveals that the sample is predominantly (69\%) high-technology firms based on HiTech_Bio=1 or HiTech_NonBio=1, with almost half of these hightechnology IPOs in the healthcare industry. The average firm has investments in intangible assets, as a percentage of operating expenses, of 28.6\% (RDAD_Exp). The sample IPOs exhibits substantial variation in size based on a mean book value of total assets of $\$ 57.5$ million, with a minimum (maximum) of $\$ 0.8$ million ( $\$ 12.1$ billion). These firms also tend to be young (the median IPO has an age of 9 years since founding, Log_Age $=2.197)$ and unprofitable. In the year prior to the IPO, firms raise new debt or equity financing, New_FIN, at a mean (median) rate of $31 \%(7.1 \%)$ of total assets. In terms of their pre-IPO information environment, $72.2 \%(81 \%)$ of the sample IPOs have venture capital backing (a Big 4 audit firm). Finally, 22.7\% of IPOs will list on the New York Stock Exchange $\left(E x c h \_N Y S E=1\right)$ and only $6.7 \%$ of maintain multiple share classes $($ DualClass $=1)$.

Summary statistics in Panel C for our IPO outcomes reveal a mean Revision (Underpricing) of $-6.1 \%(15.2 \%)$ and an average institutional stake in the post-IPO period of $1 \%$. Post-IPO analyst

\footnotetext{
${ }^{19}$ We create this variable because the JOBS Act reduces prospectus disclosure requirements for emerging growth companies, which are the bulk of the IPOs in our post-2012 sample.
} 
following is $6.8(6)$ at the mean (median), while the natural log of media coverage shows that the median firm has $42\left(e^{3.706}\right)$ Dow Jones news flashes or full articles in the one-year post-IPO period.

\subsection{Disclosures around the Securities Offering Reform}

As noted above, our identification strategy exploits passage of the SOR as a source of quasiexogenous and predictable variation for issuing visibility-enhancing pre-prospectus disclosures. We first examine the information content of press releases in the years surrounding the SOR's passage to determine whether the type and frequency of pre-prospectus disclosures indeed change as a result of this regulation. ${ }^{20}$ In Table 3, we document the disclosure category Ravenpack assigns to each of the press releases issued by IPOs for our full sample of 569 IPOs and separately for the subsamples of 99 IPOs in the pre-SOR period (with an initial SEC filing date on or before March 1, 2006) and 89 IPOs in the immediate post-SOR period (with an initial SEC filing date between March 1, 2006 and March 1, 2008). In the full sample, we find that pre-prospectus press releases primarily discuss product or service offerings (35.7\% of all press releases) followed by equity actions (21.1\%) and labor issues including executive appointments and turnovers (16.9\%). More importantly, turning to the pre- and post-SOR subsamples reveals that earnings- and revenue-related press releases occur more frequently in the pre-SOR period (8.6\% of pre-SOR vs. $1.3 \%$ of post-SOR press releases) as do press releases discussing equity actions (23.7\% of pre-SOR vs. $15.5 \%$ of post-SOR press releases), consistent with the SOR prohibiting mentions of upcoming equity issuances prior to filing a prospectus and prohibiting the release of forward-looking information. The categories that firms shift toward in their post-SOR press release issuance include those discussing labor issues (10.3\% increase), upcoming conference participation (3.0\% increase), and product/service offerings ( $7.1 \%$ increase).

Beyond this analysis, we also examine whether there are significant changes in the proportion of IPO firms employing pre-prospectus disclosures and the timing of these disclosures. The SOR

\footnotetext{
${ }^{20}$ We are unable to conduct a similar analysis of investor conferences given the small number of firms attending conferences in the pre-SOR period.
} 
liberalized pre-prospectus disclosures by providing safe harbor for permitted disclosures, specifically allowing the release of factual business information as long as the information is materially consistent with the firm's past disclosure policies (in timing, manner, and form). Consistent with this encouraging firms to engage in pre-prospectus disclosure, we find a significant increase of $12.6 \%$ (pvalue $<0.10$ ) in the proportion of IPO firms issuing press releases in the post-SOR period. ${ }^{21}$ In addition, we also find that firms issuing pre-prospectus press releases in the post-SOR regime do so more evenly over the period, based on a weighted average release time that is 146 days (97 days) prior to the prospectus filing over the one-year period for IPOs in the post-SOR (pre-SOR) regime. The significant difference of 49 days (p-value < 0.01) suggests that following the SOR, IPO firms do not cluster press releases in the period immediately before filing the prospectus. Overall, preliminary descriptive evidence for press releases in Table 3 indicates that the SOR drives predictable variation in IPO firms' use of visibility-enhancing disclosures in that pre-prospectus disclosure following the SOR increases and is tilted toward visibility-enhancing disclosures, rather than detailed and quantitative financial information. This allows us to better identify whether such disclosures have visibility enhancing effects on subsequent IPO outcomes.

\section{Main Results}

\subsection{Results of information acquisition tests (H1)}

The first prediction we develop from Merton's (1987) model concerns the relation between pre-prospectus disclosures and information acquisition by prospective investors ahead of the IPO. Specifically, we predict that firms with more extensive visibility-enhancing disclosures will experience greater information acquisition by prospective investors, consistent with these investors processing detailed firm information once they become aware of the firm's existence (i.e., in response to an increase in firm visibility).

\footnotetext{
${ }^{21}$ All p-values presented and discussed in the text are based on two-tailed tests for significance.
} 
Table 4 presents results for the natural log of EDGAR search activity $\left(\log _{-} E D G A R\right)$ during the filing period ending with the IPO offering date where Panel A (B) reports OLS regressions (entropy-balanced weighted OLS regressions). Consistent with pre-prospectus disclosures enhancing visibility (and thereby information acquisition) for prospective investors, we find a significant positive relation for pre-prospectus press releases $\left(\log _{-} P R\right)$ in both Panels A and B and an insignificant (significantly positive) relation for conference attendance (IConf) in Panel A (Panel B). In particular, models (2) - (4) in Panel A display significant positive coefficients ranging between $0.102-0.117$ on $\log _{-} P R$. Focusing on the 0.117 (0.074) coefficient estimate from model (4) in Panel A (model 3 in Panel B) for $\log _{-} P R$ implies a predicted increase in search activity of $11.1 \%$ (6.4\%) for a one-standard deviation increase in press release issuance. In addition, the entropy balancing results in Panel B suggest that the relation between pre-prospectus press releases and Log_EDGAR is significantly smaller in the pre-SOR period (coeff. $=-0.106$, p-value $<0.10)$. Turning to the results for conference attendance, the significant coefficient in model (1) in Panel B for IConf implies an increase in search activity of $22.3 \%\left(e^{0.201}-1\right)$ as a result of attending at least one conference. These estimates provide evidence of a statistically significant and economically meaningful complementary relation between voluntary pre-prospectus disclosures and the acquisition of regulated financial information during the IPO filing window that includes the IPO roadshow, the latter of which is the focus of prior research on IPO disclosure (e.g., Leone et al., 2007).

\subsection{Results of IPO pricing tests (H2)}

The second prediction we develop from Merton's (1987) model is that visibility-enhancing disclosures should positively affect investor demand for the firm's shares. Table 5 tests this prediction by providing the results of our analysis of filing price revisions (Revision) and first-day Underpricing. Prior research shows that the initial filing price range in the IPO prospectus does not capture all publicly available information (Lowry and Schwert, 2004; Willenborg et al., 2015). Coupled with Benveniste and Spindt's (1989) argument that offer price revisions reflect investor 
demand during the roadshow process, we start by examining whether a relation exists between preprospectus disclosure and the filing price revision.

Turning to Panel A of Table 5 reveals evidence of a significantly positive association between Revision and pre-prospectus disclosure. Using the OLS estimates from model (1) in Panel A reveals that investor conference attendance is associated with significant upward price revisions (IConf coeff. $=7.913$, p-value $<0.01)$. Models (3) and (4) demonstrate that this association is also largely preserved after controlling for press release issuance where press releases are significantly positively associated with price revisions in models (2) and (3) $\left(\log _{-} P R\right.$ coeff. $=3.768$ and 3.220, pvalues $<0.01$, respectively). A closer look at the results in model (4) reveals that the positive relation with press release issuance is concentrated in the post-SOR period, with a significant positive coefficient for $\log _{-} P R($ coeff. $=4.390$, p-value $<0.01)$ and a significant negative coefficient for the interaction between the PreSOR indicator and $\log _{-} P R$ (coeff. $=-4.194$, p-value $\left.<0.10\right)$. Based on estimates in model (4), a one-standard deviation increase in $L o g \_P R$ is associated with a Revision of $3.45 \%$ in the post-SOR period. Given that median proceeds are $\$ 85.5$ million, in economic terms, this translates into an additional $\$ 2.9$ million in funds raised by the firm. Since evidence of a positive relation for press releases occurs only in the post-SOR period, the inference is that there is a greater role for visibility-enhancing disclosures following the SOR reform. This inference is further enhanced by the estimates in Panel B based on the entropy-balanced control sample that are largely in line with those in Panel A, with significant positive associations between price revisions and preprospectus disclosure. The entropy-balanced results, coupled with our shock to firms' ability to provide pre-prospectus disclosures (i.e., the SOR), provide further evidence that IPO pricing is driven by the issuance of pre-prospectus disclosure rather than firm fundamentals that differ between our disclosing and non-disclosing firms.

Table 5 also presents results for Underpricing. On one hand, the results of prior research imply a negative relation between more extensive pre-IPO voluntary disclosure and IPO 
underpricing, resulting from a reduction in adverse selection costs (e.g., Boone et al., 2016; Jog and McConomy, 2003; Barth et al., 2017). This evidence is consistent with voluntary disclosures via the prospectus aiding investors in assessing a more precise distribution of value for an IPO firm and thus lowering underpricing (Leone et al., 2007), where underpricing is a function of ex ante uncertainty (Ritter, 1987; Ljungqvist, 2007). On the other hand, if underpricing reflects investor attention either from the filing price revision not fully incorporating the demand information in the filing period (Hanley, 1993) or new attention from retail investors (Cook et al., 2006), then we would observe a positive relation between pre-prospectus disclosure activities and Underpricing (H2). Consistent with elevated investor visibility following pre-prospectus disclosure, the results for models (6) - (8) in Panel A exhibit significant positive coefficients for $\log _{-} P R$. For example, the results for model (8), which incorporates the interaction between the PreSOR indicator and press release disclosure, reveals that a one-standard deviation increase in $\log _{-} P R$ is associated with $3.3 \%$ more underpricing $\left(L_{0} \_P R\right.$ coeff. $=3.3$, p-value $\left.<0.05\right)$. Similar to the results above for Revision, in model $(8)$ we also observe a negative coefficient for the PreSOR * Log_PR interaction terms. Turning to the entropybalanced estimates in Panel B, both IConf and Log_PR exhibit significant positive associations with Underpricing in models (4) - (6), with a significant negative coefficient on the PreSOR*Log_PR interaction term in model (6) (coeff. $=-3.557$, p-value $<0.05)$.

In sum, evidence of a significant positive relation between Underpricing and pre-prospectus disclosure in the post-SOR period is consistent with underpricing reflecting either (or both) a partial adjustment to investor demand by the underwriter following visibility-enhancing disclosure or increased uncertainty for firms with more extensive pre-prospectus disclosures (Ritter, 1987; Ljungqvist, 2007). In addition, our entropy balancing test procedures mitigate concerns that the relation with Underpricing is due to differing levels of pre-IPO firm-specific uncertainty as reflected in a differing distribution of fundamental covariates across disclosing and non-disclosing firms, as opposed to the effect of pre-prospectus disclosures we hypothesize. 


\subsection{Results of IPO ownership tests (H3)}

Table 6 tests our third prediction for a positive relation between ownership dispersion and pre-prospectus disclosures. Models (1) - (4) examine the relation between pre-prospectus disclosure and the count of institutional owners with an ownership stake exceeding $1 \%$ of the firms' equity in the immediate post-IPO period (Num_InstOwn>1\%). Because these tests rely on a count of owners as the dependent variable, we rely on a negative binomial regression model designed for count data following the recommendation by Rock, Sedo, and Willenborg (2000). The negative binomial model adjusts for both the discrete nature of the count variable and its truncated distribution (i.e., a lack of negative values). Consistent with greater ownership dispersion for firms with more extensive preprospectus disclosure, the results in Panel A reveal that $\log _{-} P R$ is negatively associated with the number of concentrated institutional holdings in models (2) - (4). Model (4)'s results demonstrate that the relation is more pronounced in the post-SOR period, with a significantly positive coefficient on the interaction for PreSOR $*$ Log_PR (coeff. $=0.087$, p-value $<0.05)$ consistent with a limited relation between the extent of concentrated institutional holding and pre-prospectus disclosure in preSOR periods. This inference is further supported in our entropy-balanced models in Panel B, with a significant negative coefficient on $\log _{-} P R$ in model (3), however the coefficient on interaction for PreSOR*Log_PR is insignificant in this model. Additionally, the relation between IConf and the extent of concentrated institutional holdings is insignificant in both Panels A and B, an indication that conference attendance is unassociated with ownership dispersion.

Turning to the relation between pre-prospectus disclosure and ownership dispersion (measured as the average institutional percentage stake, IO_AvgStake) in models (5) - (8) of Table 6, Panel A, we find some evidence that pre-prospectus press release issuance is associated with smaller average institutional stakes in the post-IPO period. This evidence supports our prediction of more dispersed ownership for these more visible firms following more extensive pre-prospectus disclosure activities. More specifically, examination of the results for models (6) - (8) reveals a negative 
relation between press release issuance $\left(L o g \_P R\right)$ and $I O \_A v g S t a k e$, with that relation concentrated in the post-SOR period (see model [8], where $L_{0} \_P R$ coeff. $=-0.100$, p-value $<0.05$ ). The inference here is that pre-prospectus disclosures are associated with somewhat larger institutional stakes in the pre-SOR regime, consistent with these disclosures increasing the depth rather than the breadth of ownership. However, that inference is attenuated by the results for the entropy-balanced models in Panel B, which exhibit insignificant coefficient estimates for IConf and Log_PR in models (5) - (7). In sum, results in Table 6 provide some evidence that firms with more extensive pre-prospectus press release disclosures exhibit more dispersed ownership.

\subsection{Results of post-IPO information intermediary tests (H4)}

Table 7 presents results of tests of our fourth hypothesis which predicts a positive relation between pre-prospectus disclosures and enhanced coverage by information intermediaries in the postIPO period. If pre-prospectus disclosures enhance firm visibility, then we expect higher coverage by sell-side analysts and by the financial press in the post-IPO period (e.g., Mehran and Peristiani, 2009; Bushee and Miller, 2012; Barber and Odean, 2008). Consistent with our hypothesis, models (2) - (4) in Panel A and models (2) - (3) in Panel B provide evidence of an economically significant positive association between Analyst_Count and press release issuance ( $\log _{-} P R$ coefficients range from 0.113 to 0.142 , with p-values < 0.01 ) in our negative binomial models for Analyst_Count (see Rock et al., 2000). In addition, under the entropy-balanced tests in Panel B, the relation between IConf and Analyst_Count is also significant (coeff. $=0.155$, p-value $<0.10)$. Using model (4)'s estimates in Panel A implies that a one-standard deviation increase in press release issuance in the post-SOR period is associated with a $13.5 \%$ increase in analyst following $\left(\left[e^{0.129}-1\right] * 0.978\right)$, representing 0.8 additional analysts following the firm in the first-year post-IPO relative to the median analyst following of 6. Finally, there is evidence in Panel B's model (3) that the relation between Log_PR and Analyst_Count is significantly more positive in post-SOR periods (PreSOR*Log_PR coeff. = 0.115 , p-value $<0.05)$ 
Turning to the results for media coverage by the financial press, results in models (5) - (8) (models [5] - [7]) in Panel A (B) provide evidence of a positive relation between media coverage and both press release issuance and investor conference attendance similar to our results for analyst coverage. For example, model (8) shows significant positive relations between media article mentions in the one-year post-IPO period $\left(M e d i a \_1 Y\right)$ and the indicator for investor conference attendance $($ IConf coeff. $=0.156$, p-value $<0.05)$ and the natural log of press releases $\left(\log _{-} P R\right.$ coeff. $=0.129, \mathrm{p}$-value $<0.01)$. However, in contrast to the results in for analyst coverage, we find some evidence of a more pronounced pre-SOR relation between $L o g \_P R$ and post-IPO media coverage after entropy balancing in Panel B $\left(\right.$ PreSOR $* \log _{-} P R$ coeff. $=0.218$, p-value $\left.<0.05\right)$. We interpret this as evidence that more news-worthy information is conveyed by press releases in the pre-SOR period, where firms use press releases less for visibility-enhancement prior to the reform. ${ }^{22}$ Overall, these findings indicate that after controlling for filing period financial press coverage of our sample of IPOs, voluntary disclosures serve a visibility-enhancing role that is incremental to media coverage during the roadshow period (Cook et al., 2006; Liu et al., 2014).

\subsection{Results of information asymmetry tests (H5)}

The final hypothesis we develop tests Merton's (1987, p.501) observation that visibilityenhancing disclosures are fundamentally distinct from disclosures used to "provide substantive information" to shareholders. The key implication is that any declines in information asymmetry as a result of our pre-prospectus disclosures should be limited (or zero). Table 8 tests this by reporting results where post-IPO bid-ask spreads and post-IPO equity price volatility (both measured during the 24-day quiet period) are the dependent variables. With regard to volatility, in columns (1) - (4) we find only limited evidence that pre-prospectus disclosure activities are associated with post-IPO equity price volatility. That said, we do find a negative relation between press releases and post-IPO

\footnotetext{
${ }^{22}$ In support of this inference, we find similar results when we exclude news flashes and focus only on full media articles by Dow Jones to measure post-IPO media attention.
} 
stock volatility for IPOs in the pre-SOR regime in model (4) of panel $($ PreSOR $*$ Log_PR coeff. = 0.003, p-value $<0.05)$. However, this result vanishes under the entropy balancing test design in Panel B. Turning to the bid-ask spread tests in models (5) - (8) of Panel A, we observe no significant relations between post-IPO bid-ask spreads and pre-prospectus disclosures. Collectively, Table 8's results buttress our earlier evidence and related inference that the pre-prospectus disclosure activities are most consistent with an intent to enhance firms' financial visibility rather than to ameliorate informational asymmetries.

\section{Additional Analyses}

\subsection{Results of tests for variation in managerial wealth revaluations}

One feature of our results that deserves additional attention is evidence that firms with more extensive pre-prospectus disclosures exhibit increases in equity price that are only fully realized once the IPO begins trading. This implies that the price improvement theorized in Merton (1987), and observed here empirically, is only fully incorporated subsequent to the IPO. This raises the issue of how firms directly benefit from this underpricing. To provide some evidence for why managers may leave money on the table in the form of underpricing, Table 9 examines whether managers retain shares at the IPO (to limit exposure to underpricing). Inconsistent with the idea that firms retain more shares at the IPO in order to benefit from post-IPO equity markets via follow-on offerings, models $(1)-(4)$ in Table 9 show no significant differences in ownership retention (Retain) across IPOs as a function of pre-prospectus disclosures. The lone exception is evidence of a significant positive relation in model (1) for IConf in Panel B (p-value <0.05) indicating that firms attending conferences retain $2.5 \%$ more shares at the IPO on average. Alternatively, prospect theory suggests that individuals are more concerned with changes in wealth relative to an anchored price rather than overall wealth levels (Kahneman and Tversky, 1979). To formalize this argument in an IPO setting, existing IPO owners are expected to anchor to the initial IPO filing range and are satisfied when their wealth revaluation from shares retained exceeds the money left on the table from shares sold at IPO 
(Loughran and Ritter, 2002). ${ }^{23}$ When we follow the approach by Loughran and Ritter (2002) in models $(5)-(8)$ of Table 9 , we find that insiders at firms providing more pre-prospectus disclosures (for both $L o g \_P R$ and IConf) do achieve larger wealth revaluations from their retained shares relative to the money left on the table from the IPO issuance. ${ }^{24}$ Further, we find some evidence in both Panel A and Panel B that this relation is concentrated in the post-SOR period (with significant negative coefficients on the PreSOR * Log_PR interaction). This result is consistent with managers at firms with more pre-prospectus disclosure acquiescing to a lower IPO price in the presence of large wealth revaluations, especially in the post-SOR period.

\subsection{Results of tests of pre-prospectus disclosure as underwriter promotion or hype}

The tests we report in in this section are designed to first rule out the concern that post-IPO pricing and pre-prospectus voluntary disclosure are merely artifacts of increased underwriter effort via due diligence or stock promotion. Hanley and Hoberg (2010) and Cook et al. (2006) find a positive association between proxies for underwriter effort and underwriter spreads. In unreported results we find no relation between pre-prospectus disclosures and underwriting spreads $\left(U W \_S p r e a d\right)$. In addition, all of our tests include a control for underwriter rank (TopUW), aiding in ruling out a relation with more prestigious underwriting firms. We infer that greater underwriter promotion or due diligence does not appear to explain the effects of pre-prospectus disclosure that we document. $^{25}$

Second, we examine post-IPO equity performance to rule out a "hype" story for the positive association between IPO pricing and pre-prospectus disclosures. If IPOs with more extensive pre-

\footnotetext{
${ }^{23}$ Recent IPO research (e.g., Willenborg et al., 2015; Ljungqvist and Wilhelm, 2005) finds support for the importance of wealth revaluations.

${ }^{24}$ Our measure of wealth revaluation (Wealth_Reval) is the change from the midpoint of the initial filing price range to the IPO offer price multiplied by the number of secondary shares sold plus the change from the midpoint of the initial filing price range to the first-day close price multiplied by the number of shares retained.

${ }^{25}$ We also estimated a Logit model (untabulated) predicting the TopUW indicator for whether the underwriter is classified as a top-ranked underwriter based on the order of their appearance in the "tombstone" advertisement (Carter and Manaster, 1990; Loughran and Ritter, 2004). Inconsistent with pre-prospectus disclosure reflecting the presence of more prestigious underwriters, we find no relation with this ranking as a dependent variable.
} 
prospectus disclosures are systematically over-priced as a result of investor sentiment related to these

disclosures, we should observe systematic under-performance for these IPOs relative to a portfolio of similar firms. Inconsistent with investors over-pricing the IPO at the end of the first day of trading, we find no evidence of post-IPO underperformance (measured relative to a size and book-to-market reference portfolio) over the year following the offering (untabulated) by firms with more extensive pre-prospectus disclosure. We interpret this as further evidence that pre-prospectus disclosures are designed to enhance firm visibility, and are unassociated with any systematic mispricing of the shares in the offering as a result.

\section{Conclusion}

We examine the role of pre-prospectus voluntary disclosures by firms pursuing an IPO. Drawing on Merton (1987), we hypothesize that such disclosures are used by firms to enhance visibility with prospective investors. Consistent with the benefits suggested by Merton (1987) to firms pursuing visibility-enhancing disclosures, we document that firms with more extensive preprospectus press releases display greater pre-IPO investor acquisition of regulated financial information, more positive filing price revisions and underpricing, more dispersed investor ownership, and greater coverage by information intermediaries post-IPO. We document similar (although weaker) results for firms attending investor conferences in the pre-prospectus period. In contrast to prior research on the traditional role of pre-IPO voluntary disclosure in reducing adverse selection costs (see, e.g., Leone et al. 2007), our evidence indicates that pre-prospectus disclosure activities are primarily designed to enhance firm visibility. Consistent with this inference, we find no evidence that pre-prospectus press releases reduce information asymmetry.

Evidence in this study is important for understanding the use of voluntary disclosure by private firms, an area that is far-less researched relative to disclosure for public firms (see Beyer et al., 2010 for a review). Our results suggest that by modifying their voluntary disclosure strategies as they prepare to go public, firms can capture valuable benefits beyond simply mitigating 
informational asymmetries. Our study also contributes by shedding light on the economic consequences of pre-IPO voluntary disclosures following the SEC's 2005 Securities Offering Reform that liberalized disclosure rules for issuers. In contrast to concerns that removing restrictions on disclosure would incent firms to "hype" their stock prior to raising capital (Lang and Lundholm, 2000), we find no evidence that firms with more extensive pre-prospectus disclosures display inflated prices that reverse over time. 


\section{References}

Barber, Brad M., and Terrance Odean. 2008. "All That Glitters: The Effect of Attention and News on the Buying Behavior of Individual and Institutional Investors." Review of Financial Studies 21 (2): 785-818.

Barth, Mary E., Wayne R. Landsman, and Daniel J. Taylor. 2017. "The JOBS Act and Information Uncertainty in IPO Firms." The Accounting Review 92 (6): 25-47.

Benveniste, Lawrence M., and Paul A. Spindt. 1989. "How Investment Bankers Determine the Offer Price and Allocation of New Issues." Journal of Financial Economics 24 (2): 343-361.

Beyer, A., D.A. Cohen, T.Z. Lys, and B.R. Walther. 2010. "The Financial Reporting Environment: Review of the Recent Literature." Journal of Accounting and Economics 50 (2): 296-343.

Bharath, Sreedhar T., and Amy K. Dittmar. 2010. "Why Do Firms Use Private Equity to Opt out of Public Markets?" The Review of Financial Studies 23 (5): 1771-1818.

Blankespoor, Elizabeth, Bradley E. Hendricks, and Gregory S. Miller. 2017. "Perceptions and Price: Evidence from CEO Presentations at IPO Roadshows." Journal of Accounting Research 55 (2): 275-327.

Boone, Audra L., Ioannis V. Floros, and Shane A. Johnson. 2016. "Redacting Proprietary Information at the Initial Public Offering." Journal of Financial Economics 120 (1): 102-123.

Brav, Alon, and Paul A. Gompers. 1997. "Myth or Reality? The Long-Run Underperformance of Initial Public Offerings: Evidence from Venture and Nonventure Capital-Backed Companies." The Journal of Finance 52 (5): 1791-1821.

Brown, Nerissa C., Theodore E. Christensen, Andrea Menini, and Thomas D. Steffen. 2018. "Non-GAAP Earnings Disclosure and IPO Pricing."

Bushee, Brian J., and Gregory S. Miller. 2012. "Investor Relations, Firm Visibility, and Investor Following." The Accounting Review 87 (3): 867-897.

Carter, Richard, and Steven Manaster. 1990. "Initial Public Offerings and Underwriter Reputation." The Journal of Finance 45 (4): 1045-1067.

Cedergren, Matthew C. 2014. "Joining the Conversation: How Quiet Is the IPO Quiet Period?" SSRN Scholarly Paper ID 2536004. Rochester, NY: Social Science Research Network. http://papers.ssrn.com/abstract=2536004.

Chaplinsky, Susan, Kathleen Weiss Hanley, and S. Katie Moon. 2017. "The JOBS Act and the Costs of Going Public." Journal of Accounting Research 55 (4): 795-836.

Chemmanur, Thomas J., and Paolo Fulghieri. 1999. "A Theory of the Going-Public Decision." The Review of Financial Studies 12 (2): 249-279.

Chemmanur, Thomas, and An Yan. 2009. "Product Market Advertising and New Equity Issues." Journal of Financial Economics 92 (1): 40-65.

Clinton, Sarah B., Joshua T. White, and Tracie Woidtke. 2014. "Differences in the Information Environment Prior to Seasoned Equity Offerings under Relaxed Disclosure Regulation." Journal of Accounting and Economics 58 (1): 59-78.

Cook, Douglas O., Robert Kieschnick, and Robert A. Van Ness. 2006. "On the Marketing of IPOs." Journal of Financial Economics 82 (1): 35-61.

Dambra, Michael, Laura Casares Field, and Matthew T. Gustafson. 2015. "The JOBS Act and IPO Volume: Evidence That Disclosure Costs Affect the IPO Decision." Journal of Financial Economics 116 (1): 121-143.

Dambra, Michael, Matthew Gustafson, and Kevin Pisciotta. 2018. "IPO Size and the Benefits to Going Public." SSRN Scholarly Paper ID 2958409. Rochester, NY: Social Science Research Network. https://papers.ssrn.com/abstract=2958409. 
Demers, Elizabeth, and Katharina Lewellen. 2003. "The Marketing Role of IPOs: Evidence from Internet Stocks." Journal of Financial Economics 68 (3): 413-437.

Drake, Michael S., Darren T. Roulstone, and Jacob R. Thornock. 2015. "The Determinants and Consequences of Information Acquisition via EDGAR." Contemporary Accounting Research 32 (3): 1128-1161.

Feng, Mei, loannis V. Floros, Shane A. Johnson, and Zhejia Ling. 2018. "Walking the Line between Reducing Information Asymmetry and Protecting Proprietary Information: Management Forecasts by Newly Public Firms." SSRN Scholarly Paper ID 3225230. Rochester, NY: Social Science Research Network. https://papers.ssrn.com/abstract=3225230.

Field, Laura C. 1995. "Is Institutional Investment in Initial Public Offerings Related to Long-Run Performance of These Firms?"

Field, Laura Casares, and Jonathan M. Karpoff. 2002. "Takeover Defenses of IPO Firms." The Journal of Finance 57 (5): 1857-1889.

Green, T. Clifton, Russell Jame, Stanimir Markov, and Musa Subasi. 2014. "Broker-Hosted Investor Conferences." Journal of Accounting and Economics 58 (1): 142-166.

Guo, Re-Jin, Baruch Lev, and Nan Zhou. 2004. "Competitive Costs of Disclosure by Biotech IPOs." Journal of Accounting Research 42 (2): 319-355.

Hainmueller, Jens. 2012. "Entropy Balancing for Causal Effects: A Multivariate Reweighting Method to Produce Balanced Samples in Observational Studies." Political Analysis 20 (1): 25-46.

Hanley, Kathleen Weiss. 1993. "The Underpricing of Initial Public Offerings and the Partial Adjustment Phenomenon." Journal of Financial Economics 34 (2): 231-250.

Hanley, Kathleen Weiss, and Gerard Hoberg. 2010. "The Information Content of IPO Prospectuses." Review of Financial Studies 23 (7): 2821-2864.

Hoberg, Gerard, Gordon Phillips, and Nagpurnanand Prabhala. 2014. "Product Market Threats, Payouts, and Financial Flexibility." The Journal of Finance 69 (1): 293-324.

Jeon, Jin Q., Cheolwoo Lee, Tareque Nasser, and M. Tony Via. 2015. "Multiple Lead Underwriter IPOs and Firm Visibility." Journal of Corporate Finance 32: 128-149.

Jog, Vijay, and Bruce J. McConomy. 2003. "Voluntary Disclosure of Management Earnings Forecasts in IPO Prospectuses." Journal of Business Finance \& Accounting 30 (1-2): 125-168.

Jones, Denise A. 2007. "Voluntary Disclosure in R\&D-Intensive Industries*." Contemporary Accounting Research 24 (2): 489-522.

Kasznik, Ron, and Baruch Lev. 1995. "To Warn or Not to Warn: Management Disclosures in the Face of an Earnings Surprise." Accounting Review, 113-134.

Lang, Mark H., and Russell J. Lundholm. 2000. "Voluntary Disclosure and Equity Offerings: Reducing Information Asymmetry or Hyping the Stock?" Contemporary Accounting Research 17 (4): 623662.

Leone, A., S. Rock, and M. Willenborg. 2007. "Disclosure of Intended Use of Proceeds and Underpricing in Initial Public Offerings." Journal of Accounting Research 45 (1): 111.

Leone, Andrew J., Miguel Minutti-Meza, and Charles E. Wasley. 2015. "Influential Observations and Inference in Accounting Research." https://papers.ssrn.com/sol3/papers.cfm?abstract_id=2407967.

Li, Kevin K., and Haifeng You. 2015. "What Is the Value of Sell-Side Analysts? Evidence from Coverage Initiations and Terminations." Journal of Accounting and Economics 60 (2-3): 141-160.

Liu, Laura Xiaolei, Ann E. Sherman, and Yong Zhang. 2014. "The Long-Run Role of the Media: Evidence from Initial Public Offerings." Management Science 60 (8): 1945-1964.

Ljungqvist, Alexander. 2007. "IPO Underpricing." Handbook of Corporate Finance: Empirical Corporate Finance 1: 375-422. 
Ljungqvist, Alexander, and William J. Wilhelm. 2005. "Does Prospect Theory Explain IPO Market Behavior?" The Journal of Finance 60 (4): 1759-1790.

Loughran, Tim, and Bill McDonald. 2013. "IPO First-Day Returns, Offer Price Revisions, Volatility, and Form S-1 Language." Journal of Financial Economics 109 (2): 307-326.

Loughran, Tim, and Jay Ritter. 2004. "Why Has IPO Underpricing Changed over Time?" Financial Management, 5-37.

Loughran, Tim, and Jay R. Ritter. 2002. "Why Don't Issuers Get Upset about Leaving Money on the Table in IPOs?" Review of Financial Studies 15 (2): 413-444.

Lowry, Michelle, Roni Michaely, and Ekaterina Volkova. 2017. "Initial Public Offering: A Synthesis of the Literature and Directions for Future Research." Foundations and Trends ${ }^{\circledR}$ in Finance 11 (3-4): 154-320. http://dx.doi.org/10.1561/0500000050.

Lowry, Michelle, and G. William Schwert. 2004. "Is the IPO Pricing Process Efficient?" Journal of Financial Economics 71 (1): 3-26.

McMullin, Jeff L., and Bryce Schonberger. 2015. "Entropy-Balanced Discretionary Accruals." SSRN Scholarly Paper ID 2556389. Rochester, NY: Social Science Research Network. http://papers.ssrn.com/abstract=2556389.

Mehran, Hamid, and Stavros Peristiani. 2009. "Financial Visibility and the Decision to Go Private." The Review of Financial Studies 23 (2): 519-547.

Merton, Robert C. 1987. "A Simple Model of Capital Market Equilibrium with Incomplete Information." The Journal of Finance 42 (3): 483-510.

Ritter, Jay R. 1987. "The Costs of Going Public." Journal of Financial Economics 19 (2): 269-281.

Rock, Steve, Stanley Sedo, and Michael Willenborg. 2000. "Analyst Following and Count-Data Econometrics." Journal of Accounting and Economics 30 (3): 351-373.

Rosenbaum, Paul R., and Donald B. Rubin. 1983. "The Central Role of the Propensity Score in Observational Studies for Causal Effects." Biometrika 70 (1): 41-55.

Rubin, Donald B. 2001. "Using Propensity Scores to Help Design Observational Studies: Application to the Tobacco Litigation." Health Services and Outcomes Research Methodology 2 (3): 169-188.

Schrand, Catherine M., and Robert E. Verrecchia. 2005. "Information Disclosure and Adverse Selection Explanations for IPO Underpricing." SSRN Scholarly Paper ID 316824. Rochester, NY: Social Science Research Network. https://papers.ssrn.com/abstract=316824.

Securities and Exchange Commission (SEC). 2005. Securities Offering Reform. FILE NO. S7-38-04.

Shipman, Jonathan E., Quinn T. Swanquist, and Robert L. Whited. 2017. "Propensity Score Matching in Accounting Research." The Accounting Review 92 (1): 213-244.

Shroff, Nemit, Amy X. Sun, Hal D. White, and Weining Zhang. 2013. "Voluntary Disclosure and Information Asymmetry: Evidence from the 2005 Securities Offering Reform." Journal of Accounting Research 51 (5): 1299-1345.

Smart, Scott B., and Chad J. Zutter. 2003. "Control as a Motivation for Underpricing: A Comparison of Dual and Single-Class IPOs." Journal of Financial Economics 69 (1): 85-110.

Tversky, Amos, and Daniel Kahneman. 1974. "Judgment under Uncertainty: Heuristics and Biases." Science 185 (4157): 1124-1131.

Verrecchia, Robert E. 1983. "Discretionary Disclosure." Journal of Accounting and Economics 5: 179-194.

Weber, Joseph, and Michael Willenborg. 2003. "Do Expert Informational Intermediaries Add Value? Evidence from Auditors in Microcap Initial Public Offerings." Journal of Accounting Research 41 (4): 681-720.

Willenborg, Michael, Biyu Wu, and Yanhua Sunny Yang. 2015. "Issuer Operating Performance and IPO Price Formation." Journal of Accounting Research 53 (5): 1109-1149. 


\section{Appendix A \\ Detailed Variable Definitions and Data Sources}

\begin{tabular}{|c|c|}
\hline Variable & Description \\
\hline Analyst_Count & $\begin{array}{l}\text { The number of unique analysts issuing earnings per share forecasts in I/B/E/S for the firm during the } 12 \text { - } \\
\text { month post-IPO period beginning on day } t+1 \text { following the IPO offering date. }\end{array}$ \\
\hline Bank & $\begin{array}{l}\text { An indicator set to one for IPOs with a primary Standard Industrial Classification (SIC) on SDC Platinum } \\
\text { that falls in the financial services industry (SIC codes: } 6000 \text { - 6999). }\end{array}$ \\
\hline BHARIY & $\begin{array}{l}\text { Buy-and-hold abnormal return calculated using CRSP daily return data for the firm's one-year post-IPO } \\
\text { return beginning on day } t+1 \text { following the IPO offering date. Abnormal return is based on subtracting the } \\
\text { corresponding one-year buy-and-hold return to the firm's Fama-French } 5 \text { x } 5 \text { size and B/M portfolio } \\
\text { available from Kenneth French's website: } \\
\text { (http://mba.tuck.dartmouth.edu/pages/faculty/ken.french/data_library.html) }\end{array}$ \\
\hline BA_Spread1M & $\begin{array}{l}\text { The average of the daily ask - bid spread scaled by closing price for the } 24 \text { day quiet period beginning on } \\
\text { day } t+1 \text { following the IPO offering date (source: CRSP). }\end{array}$ \\
\hline Big4 & $\begin{array}{l}\text { An indicator variable set to one for auditors with a rank of } 1-8 \text { in COMPUSTAT to capture IPOs audited } \\
\text { by Deloitte, Ernst and Young, KPMG, and PricewaterhouseCoopers (and predecessors), and zero otherwise. }\end{array}$ \\
\hline DualClass & $\begin{array}{l}\text { An indicator variable set to one for issuers with multiple classes of shares, zero otherwise. Data on share } \\
\text { classes are available on Jay Ritter's website: https://site.warrington.ufl.edu/ritter/ipo-data/ }\end{array}$ \\
\hline Exch_NYSE & An indicator variable set to one for firms listing on the New York Stock Exchange, and zero otherwise. \\
\hline HiTech_Bio & $\begin{array}{l}\text { An indicator variable set to one for IPOs classified as primarily operating in a high technology industry by } \\
\text { SDC Platinum and that operate in the healthcare industry based on the Fama-French 10-industry } \\
\text { classification, and zero otherwise. SDC's classification is more detailed than that available through Standard } \\
\text { Industrial Classification (SIC) industry codes. Data on the } 10 \text {-industry classification is available from Ken } \\
\text { French's website: (http://mba.tuck.dartmouth.edu/pages/faculty/ken.french/data_library.html) }\end{array}$ \\
\hline HiTech_NonBio & $\begin{array}{l}\text { An indicator variable set to one for IPOs classified as primarily operating in a high technology industry by } \\
\text { SDC Platinum, but which do not operate in the healthcare industry based on the Fama-French 10-industry } \\
\text { classification, and zero otherwise. SDC's classification of high-technology firms is more detailed than that } \\
\text { available through Standard Industrial Classification (SIC) industry codes. }\end{array}$ \\
\hline IConf & $\begin{array}{l}\text { An indicator variable for IPO firms attending at least one investor conference in the 12-month period ending } \\
\text { with the filing of their IPO prospectus. Conference attendance is from Bloomberg's EVTS database } \\
\text { beginning in } 2003 \text { for event types tagged as Corporate Access, Analyst Marketing, and TV/Conf/Pres. } \\
\text { Conference location in Bloomberg is unrestricted and may occur outside of the United States. We identify } \\
\text { firms as attending investor conferences if they issue at least one press release in Ravenpack in the pre- } \\
\text { prospectus period where the type is listed as "conference-participant." Based on a manual reading of these } \\
\text { press releases, they are issued for similar investor conferences to those covered by Bloomberg. }\end{array}$ \\
\hline InstOwn & $\begin{array}{l}\text { The percentage of institutional ownership of the IPO firms' equity as of the first available reporting date in } \\
\text { Thomson Reuters following the IPO offering date. The initial measurement date of institutional ownership is } \\
\text { restricted to occur during the } 12 \text { month period following the IPO. }\end{array}$ \\
\hline IPOCount_90 & The number of firms filing for an IPO in the 90 days prior to firm $i$ 's offering date. \\
\hline Log_AGE & $\begin{array}{l}\text { Natural log of firm age available from the Field-Ritter dataset (Field and Karpoff, 2002; Loughran and } \\
\text { Ritter, 2004) available on Jay Ritter's website: https://site.warrington.ufl.edu/ritter/ipo-data/ }\end{array}$ \\
\hline $\log \__{-} A T$ & $\begin{array}{l}\text { Natural log of the book value of total assets in the firm's last available 10-K report (from COMPUSTAT) } \\
\text { with a fiscal year-end date prior to the firm's IPO offering date. }\end{array}$ \\
\hline Log_EDGAR & $\begin{array}{l}\text { Natural log of the number of searches for regulatory documents available on the U.S. Security and Exchange } \\
\text { Commission's EDGAR site during the filing period ending with the IPO offering date. Searches originating } \\
\text { from IP addresses associated with automated data retrieval services are eliminated following the approach } \\
\text { by Drake, Roulstone, and Thornock (2015). }\end{array}$ \\
\hline $\begin{array}{l}\text { Log_Media_1Y } \\
\text { [Media_PreIPO] }\end{array}$ & $\begin{array}{l}\text { For each sample IPO firm, the natural log of the number of media articles with a novelty score of } 100 \text { and a } \\
\text { relevance score of } 100 \text { (which serves to identify the first-release articles written specifically about the firm) } \\
\text { available via Ravenpack's Dow Jones Edition (Version 4.0) during the 12-month post-IPO period beginning } \\
\text { on day } t+1 \text { following the IPO offering date [i.e., during the filing period beginning with the prospectus filing } \\
\text { date and ending with the IPO offering date]. }\end{array}$ \\
\hline
\end{tabular}


$\log _{-} P R$

[PR_Dum]

(at

$L_{0} \_R E V T$

Money_Left

NasdaqRET_90

NasdaqRET_File

New_FIN

Num_InstOwn $>1 \%$

\begin{tabular}{|l|l}
\hline PostJOBS & An \\
\hline
\end{tabular}

PreSOR

PreSOR

RDAD_Exp

\begin{tabular}{|l|l|}
\hline Retain & $\begin{array}{l}\text { Th } \\
\text { Revision }\end{array}$ \\
\hline ROA & P \\
\hline & Ret \\
\hline
\end{tabular}

STD_ARETIM

\begin{tabular}{l|l} 
& K \\
\hline & A
\end{tabular}

TopUW

Underpring

\begin{tabular}{|l|l|}
\hline Underpricing & Th \\
\hline$U W \_S p r e a d$ & Tref \\
\hline$V C$ & In \\
\hline & IPO \\
\hline
\end{tabular}

Wealth_Reval

Wealth_Diff(rank)
Natural $\log$ of $1+$ the count of press releases issued in the 12-month period ending with the prospectus filing. Press releases are retrieved from Ravenpack's Dow Jones and PR Editions for Version 4.0 which cover major newswires including Dow Jones, PR Newswire, and BusinessWire. Ravenpack's coverage for its Dow Jones (PR) Edition begins in 2000 (2004) with press release coverage back-filled for all entities added on or before July 28, 2014. Press releases must have a relevance score of 100 (i.e., be directly about the firm) and a novelty score of 100 (i.e., first instance of this press release). We exclude press releases with a type of "conference-organizer" as these stem from brokerage houses announcing individual attendees at a hosted conference, resulting in essentially duplicate press releases.

Natural $\log$ of $1+$ Total Revenue in the firm's last available 10-K report (from COMPUSTAT) with a fiscal year-end date prior to the firm's IPO offering date.

Money-left-on-the-table (in \$millions) measured as the difference between the first-day closing price and the IPO offer price multiplied by the number of shares included in the IPO proceeds.

Value-weighted buy-and-hold return to the NASDAQ index over the 90 day window ending 1 day prior to the firm's IPO date (source: CRSP).

Value-weighted buy-and-hold return to the NASDAQ index for the period starting with the filing of the initial price range for the IPO and ending 1 day prior to the firm's IPO date (source: CRSP).

New debt and equity financing listed in the firm's last available 10-K report (from COMPUSTAT) with a fiscal year-end date prior to the firm's IPO offering date. New financing amounts are measured following Hoberg and Phillips (2010) as [(common and preferred stock sold - equity repurchased) + (long-term debt issuance - debt retired)] / book value of total assetst-1.

The count of the number of institutional owners holding more than 1\% of the IPO firms' equity as of the first available reporting date in Thomson Reuters following the IPO offering date. The initial measurement date of institutional ownership is restricted to occur during the 12 month period following the IPO.

An indicator variable set to one for IPOs with an offering date after the Jumpstart Our Business Startups Act (JOBS Act) was signed into law on April 4, 2012 and zero otherwise.

An indicator variable set to one for IPOs with an initial SEC filing date on or before March 1, 2006 to allow for 9 out of 12 months during the one-year pre-prospectus period to overlap with the period prior to the passage of the Securities Offering Reform (SOR) on December 1, 2005, and zero otherwise.

The proportion of operating expenses accounted for by research and development and advertising listed in the firm's first post-IPO 10-K report (from COMPUSTAT) for the fiscal year-end date prior to the offering (measured as (R\&D + Advertising) / (Cost of goods sold + Selling, general, and administrative expenses). The percentage of equity shares retained by the firm at the IPO, measured as 1 - (Shares included in IPO proceeds / Total shares outstanding after offer (source: SDC or CRSP).

Percentage change from the mid-point of the original IPO filing price range to the final offer price.

Return on assets computed using information in the firm's last available 10-K report (from COMPUSTAT) with a fiscal year-end prior to the firm's IPO offering date (measured as Net Income / Total Assets). Post-IPO idiosyncratic equity return volatility for the 24-day quiet period beginning day $t+1$ following the IPO offering date and measured as the standard deviation of daily abnormal returns measured as the firm's daily return minus the daily return to the firm's Fama-French 5 x 5 size and B/M portfolio available from Kenneth French's website: (http://mba.tuck.dartmouth.edu/pages/faculty/ken.french/data library.html)

An indicator variable set to one for IPOs where the lead underwriter has a reputation rank of 9 (the highest rank available) based on the average order of appearance by the underwriter in the prospectus for IPOs underwritten over five-year windows beginning in 1980 (see Loughran and Ritter, 2004, Appendix C for details). Rankings are available from Jay Ritter's website: (https://site.warrington.ufl.edu/ritter/files/2016/06/Underwriter-Rank-1980-2015.xls).

The first-day percentage change in equity price calculated as (first-day closing price / offer price - 1) less the value-weighted return to the CRSP market index.

The percentage of IPO proceeds charged by the underwriter as compensation for managing the IPO (also referred to as the gross spread).

An indicator variable set to one for IPOs with venture capital funding (source: SDC), and zero otherwise. IPO shareholder wealth revaluation (in \$millions) measured by the change from the midpoint of the initial filing price range to the offer price multiplied by number of secondary shares sold plus the change from the midpoint of the initial filing price range to the first-day close price multiplied by number of shares retained. The IPO shareholder wealth difference is the rank (from zero to one) of the difference between the Wealth_Reval and the Money_Left measures based on the approach by Loughran and Ritter (2002). 


\section{Appendix B}

Table B.1

\section{Cross-Sectional Determinants of Pre-prospectus Disclosure:}

Logit (OLS) regression models for the indicator (continuous) variable IConf $\left(\log _{-} P R\right)$. IConf is set to one for IPOs firms that attend an investor conference in the 12-month period prior to the filing of its IPO prospectus, and to zero otherwise. $\log _{-} P R$ is the natural log of $1+$ number of press releases in Ravenpack issued by an IPO firm in the 12month period prior to the filing of its IPO the prospectus. Standard errors clustered by calendar quarter are presented in parentheses below the coefficients. The area under the receiver operating characteristic (ROC) curve is provided as a measure of Logit model fit. *,**, and *** denote two-tailed p-values significant at a $10 \%, 5 \%$, and $1 \%$ level, respectively. See Appendix A for detailed variable definitions.

\begin{tabular}{|c|c|c|}
\hline Dependent Variable & IConf & Log_PR \\
\hline Model & (1) & (2) \\
\hline \multirow[t]{2}{*}{ PreSOR } & $-1.759 * * *$ & $-0.426 * * *$ \\
\hline & $(-3.334)$ & $(-4.705)$ \\
\hline \multirow[t]{2}{*}{ PostJOBS } & $1.746 * * *$ & 0.166 \\
\hline & $(4.724)$ & $(1.421)$ \\
\hline \multirow[t]{2}{*}{ ProdMktFluid } & $0.207 * * *$ & $0.044 * * *$ \\
\hline & $(4.053)$ & $(3.690)$ \\
\hline \multirow[t]{2}{*}{ DualClass } & -0.293 & -0.159 \\
\hline & $(-0.466)$ & $(-1.126)$ \\
\hline \multirow[t]{2}{*}{ Log_AT } & 0.203 & $0.054 *$ \\
\hline & $(0.916)$ & $(1.870)$ \\
\hline \multirow[t]{2}{*}{ Log_REVT } & -0.038 & $0.082 * * *$ \\
\hline & $(-0.268)$ & $(2.954)$ \\
\hline \multirow[t]{2}{*}{ ROA } & $-0.345^{*}$ & 0.011 \\
\hline & $(-1.680)$ & $(0.214)$ \\
\hline \multirow[t]{2}{*}{ Big4 } & $1.389 * * *$ & $0.212 * *$ \\
\hline & $(2.998)$ & $(2.059)$ \\
\hline \multirow[t]{2}{*}{ RDAD_Exp } & 0.628 & $0.545^{* * *}$ \\
\hline & $(0.767)$ & $(3.092)$ \\
\hline \multirow[t]{2}{*}{ New_FIN } & 0.032 & $0.239 * * *$ \\
\hline & $(0.150)$ & $(2.911)$ \\
\hline \multirow[t]{2}{*}{$\mathrm{VC}$} & 0.120 & $0.469 * * *$ \\
\hline & $(0.202)$ & $(4.352)$ \\
\hline \multirow[t]{2}{*}{ Log_Age } & -0.079 & 0.002 \\
\hline & $(-0.328)$ & $(0.043)$ \\
\hline \multirow[t]{2}{*}{ HiTech_NonBio } & $1.509 * *$ & $0.483 * * *$ \\
\hline & $(1.973)$ & $(5.048)$ \\
\hline \multirow{2}{*}{ HiTech_Bio } & 0.983 & -0.163 \\
\hline & $(1.565)$ & $(-1.320)$ \\
\hline \multirow[t]{2}{*}{ Bank } & -1.045 & -0.164 \\
\hline & $(-1.104)$ & $(-1.205)$ \\
\hline \multirow[t]{2}{*}{ Constant } & $-7.374 * * *$ & $-0.524 * * *$ \\
\hline & $(-7.113)$ & $(-2.870)$ \\
\hline Observations & 569 & 569 \\
\hline ROC / Adjusted R ${ }^{2}$ & 0.881 & 0.308 \\
\hline
\end{tabular}




\section{Appendix B, continued}

\section{Table B.2}

\section{Results of covariate balance before and after entropy-balancing}

The table reports on the covariate balance before and after implementing entropy balancing (Hainmueller, 2012). Entropy balancing (EB) is used to identify a weighted control sample of IPOs with the same mean, variance, and skewness as the treatment sample on all selected covariates. The covariates selected for inclusion in the entropy balancing tests are those found to be significant determinants of pre-prospectus disclosures in Table B.1 of this Appendix. Panel A uses firms attending investor conferences as the treatment sample and assigns weights to control firms that do not attend these conferences in the pre-prospectus period. Panel B uses firms that issue press releases during the 12-month pre-prospectus period as the treatment sample and assigns weights to firms not issuing press releases as the control sample. The match ratio (see McMullin and Schonberger, 2015) is used to assess the number of control sample observations receiving above equal weights relative to the full control sample (a ratio of 0.5 indicates an even reweighting). To assess covariate balance for each covariate, we compute standardized differences calculated as the difference in means between treated and control samples divided by the standard deviation of the treated sample. Variance ratios are calculated as the ratio of the variance of each covariate in the treatment sample scaled by variance for the control sample. $\dagger$ denotes covariates with standardized differences (variance ratios) outside of the +/- 0.1 (4/5 and 5/4) bounds suggested by Rubin (2001) for a balanced covariate. See Appendix A for detailed variable definitions.

Panel A: Covariate balance for firms attending (treated) vs. not attending (control) investor conferences in the pre-prospectus period

\begin{tabular}{|c|c|c|c|c|c|c|c|c|}
\hline \multirow{2}{*}{$\begin{array}{l}\text { Prior to matching: } \\
\text { Covariate }\end{array}$} & \multicolumn{3}{|c|}{ Attending Conference (95 IPOs) } & \multicolumn{3}{|c|}{ No Conferences (474 IPOs) } & \multicolumn{2}{|c|}{ Balance Statistics } \\
\hline & Mean & Variance & Skewness & Mean & Variance & Skewness & Std Diff & Variance Ratio \\
\hline ProdMktFluid & 12.140 & 19.330 & 0.060 & 9.221 & 15.540 & 0.994 & $0.151 \dagger$ & 1.244 \\
\hline ROA & -0.785 & 0.882 & -2.064 & -0.256 & 0.458 & -4.959 & $-0.600 \dagger$ & $1.925 \dagger$ \\
\hline Big4 & 0.937 & 0.060 & -3.592 & 0.785 & 0.169 & -1.386 & $2.542 \dagger$ & $0.353 \dagger$ \\
\hline HiTech_NonBio & 0.295 & 0.210 & 0.900 & 0.367 & 0.233 & 0.552 & $-0.345 \dagger$ & 0.902 \\
\hline \multicolumn{9}{|l|}{ After EB: } \\
\hline Covariate & Mean & Variance & Skewness & Mean & Variance & Skewness & Std Diff & Variance Ratio \\
\hline ProdMktFluid & 12.140 & 19.330 & 0.060 & 12.140 & 19.330 & 0.060 & 0.000 & 1.000 \\
\hline ROA & -0.785 & 0.882 & -2.064 & -0.785 & 0.882 & -2.064 & 0.000 & 1.000 \\
\hline Big4 & 0.937 & 0.060 & -3.592 & 0.937 & 0.059 & -3.590 & 0.000 & 1.008 \\
\hline HiTech_NonBio & 0.295 & 0.210 & 0.900 & 0.295 & 0.208 & 0.900 & 0.000 & 1.009 \\
\hline Match Ratio & 0.27 & Ratio: $\mathrm{F}$ & with abo & qual & hts in e-l & ance / All & trol firms & \\
\hline
\end{tabular}


Table B.2, continued

Panel B: Covariate balance for firms issuing press releases (treated) vs. firms without press releases (control) in the pre-prospectus period

\begin{tabular}{|c|c|c|c|c|c|c|c|c|}
\hline \multirow{2}{*}{$\begin{array}{l}\text { Prior to matching: } \\
\text { Covariate }\end{array}$} & \multicolumn{3}{|c|}{ Issuing Press Releases (384 IPOs) } & \multicolumn{3}{|c|}{ No Press Releases (185 IPOs) } & \multicolumn{2}{|c|}{$\underline{\text { Balance Stats }}$} \\
\hline & Mean & Variance & Skewness & Mean & Variance & Skewness & Std Diff & Variance Ratio \\
\hline Log_REVT & 3.159 & 3.865 & -0.279 & 3.611 & 3.061 & -0.422 & $-0.117 \dagger$ & $1.263 \dagger$ \\
\hline RDAD_Exp & 0.358 & 0.093 & 0.557 & 0.136 & 0.048 & 2.073 & $2.382 \dagger$ & $1.930 \dagger$ \\
\hline ProdMktFluid & 10.230 & 18.370 & 0.718 & 8.624 & 13.480 & 0.952 & 0.087 & $1.363 \dagger$ \\
\hline New_FIN & 0.364 & 0.244 & 1.465 & 0.199 & 0.138 & 2.003 & $0.676 \dagger$ & $1.766 \dagger$ \\
\hline $\mathrm{VC}$ & 0.857 & 0.123 & -2.037 & 0.443 & 0.248 & 0.229 & $3.363 \dagger$ & $0.496 \dagger$ \\
\hline Big4 & 0.867 & 0.116 & -2.164 & 0.692 & 0.214 & -0.831 & $1.518 \dagger$ & $0.539 \dagger$ \\
\hline HiTech_NonBio & 0.404 & 0.241 & 0.393 & 0.254 & 0.191 & 1.130 & $0.620 \dagger$ & $1.267 \dagger$ \\
\hline \multicolumn{9}{|l|}{ After EB: } \\
\hline Covariate & Mean & Variance & Skewness & Mean & Variance & Skewness & Std Diff & Variance Ratio \\
\hline Log_REVT & 3.159 & 3.865 & -0.279 & 3.160 & 3.861 & -0.281 & 0.000 & 1.001 \\
\hline RDAD_Exp & 0.358 & 0.093 & 0.557 & 0.358 & 0.093 & 0.560 & 0.007 & 1.000 \\
\hline ProdMktFluid & 10.230 & 18.370 & 0.718 & 10.230 & 18.380 & 0.718 & 0.000 & 0.999 \\
\hline New_FIN & 0.364 & 0.244 & 1.465 & 0.363 & 0.244 & 1.467 & 0.002 & 1.001 \\
\hline $\mathrm{VC}$ & 0.857 & 0.123 & -2.037 & 0.855 & 0.125 & -2.016 & 0.015 & 0.986 \\
\hline Big4 & 0.867 & 0.116 & -2.164 & 0.866 & 0.116 & -2.154 & 0.007 & 0.992 \\
\hline HiTech_NonBio & 0.404 & 0.241 & 0.393 & 0.403 & 0.242 & 0.395 & 0.002 & 0.998 \\
\hline Match Ratio & 0.28 & and 5 & vit & a & 14. & e / All cor & l firms & \\
\hline
\end{tabular}


Table 1

Sample Selection for IPOs with filing dates on or after January 1, 2004 and an offering date on or before July 28, 2014

Sample selection details (Panel A) and a frequency distribution of the final sample by year (Panel B). See Appendix A for detailed variable definitions.

Panel A: Sample selection

Observations

Initial public offerings for U.S. firms in SDC Platinum with a non-missing CUSIP where

the issue is common stock and the filing date is on or after 1/1/2004 and the offer date is before $7 / 29 / 2014$ (sample period is designed to align with coverage by

Ravenpack and Bloomberg)

Less: IPOs that were previously leveraged buyouts, spin-offs, limited partnership offerings, trusts, closed end funds, open end funds, or special purpose entities.

Less: Observations without a valid link to COMPUSTAT based on historical CUSIP.

Less: Observations filing with the SEC more than 3 months prior to the IPO (typically firms with publicly-traded debt).

Less: Observations missing data foe variables related to underpricing, price revisions, underwriter spread, firm age from Jay Ritter's IPO data, post-IPO reference portfolio returns in CRSP, post-IPO institutional ownership from Thomson Reuters, or annual COMPUSTAT data prior to the IPO

Less: Observations with media coverage in the form of full articles appearing on the

Dow Jones Edition of Ravenpack in the one-year period extending from 12 - 24 months prior to filing the IPO prospectus.

Less: Outlying observations.

Final sample of IPOs

Panel B: Yearly frequency of IPOs in the full sample and sub-samples of IPOs attending investor conferences or issuing press releases in the pre-prospectus period

\begin{tabular}{c|cc|cc|cc}
\hline \multirow{2}{*}{ Offer Year } & \multicolumn{2}{|c|}{ Full Sample } & \multicolumn{2}{c|}{$\begin{array}{c}\text { Pre-Prospectus } \\
\text { Investor Conferences }\end{array}$} & \multicolumn{2}{c}{$\begin{array}{c}\text { Pre-Prospectus } \\
\text { Press Releases }\end{array}$} \\
\cline { 2 - 7 } & Frequency & \% of Sample & Frequency & $\begin{array}{c}\text { \% of IPOs } \\
\text { (row \%) }\end{array}$ & Frequency & $\begin{array}{c}\text { \% of IPOs } \\
\text { (row \%) }\end{array}$ \\
\hline 2004 & 83 & $14.6 \%$ & 1 & $1.2 \%$ & 44 & $53.0 \%$ \\
2005 & 63 & $11.1 \%$ & 3 & $4.8 \%$ & 32 & $50.8 \%$ \\
2006 & 74 & $13.0 \%$ & 8 & $10.8 \%$ & 50 & $67.6 \%$ \\
2007 & 78 & $13.7 \%$ & 9 & $11.5 \%$ & 53 & $67.9 \%$ \\
2008 & 10 & $1.8 \%$ & 0 & $0.0 \%$ & 8 & $80.0 \%$ \\
2009 & 12 & $2.1 \%$ & 1 & $8.3 \%$ & 7 & $58.3 \%$ \\
2010 & 48 & $8.4 \%$ & 4 & $8.3 \%$ & 33 & $68.8 \%$ \\
2011 & 36 & $6.3 \%$ & 9 & $25.0 \%$ & 25 & $69.4 \%$ \\
2012 & 33 & $5.8 \%$ & 10 & $30.3 \%$ & 30 & $90.9 \%$ \\
2013 & 70 & $12.3 \%$ & 33 & $47.1 \%$ & 61 & $87.1 \%$ \\
2014 & 62 & $10.9 \%$ & 17 & $27.4 \%$ & 41 & $66.1 \%$ \\
& & & & & & 38 \\
\end{tabular}


Table 2

Descriptive statistics for the final sample of 569 IPOs with a filing date after 1/1/2004 and an offering date prior to $7 / 28 / 2014$ with data available to calculate the determinants of pre-prospectus disclosure and IPO outcome variables

This table presents summary statistics for variables used in our analysis. See Appendix A for detailed variable definitions.

\begin{tabular}{|c|c|c|c|c|c|c|c|}
\hline Variable & Mean & Std. Dev. & Min & Q1 & Median & Q3 & Max \\
\hline \multicolumn{8}{|c|}{ Panel A: Disclosure and Regulatory Variables } \\
\hline IConf & 0.167 & 0.373 & 0 & 0 & 0 & 0 & 1 \\
\hline Log_PR & 1.127 & 0.978 & 0.000 & 0.000 & 1.099 & 1.946 & 4.060 \\
\hline PreSOR & 0.315 & 0.465 & 0 & 0 & 0 & 1 & 1 \\
\hline PostJOBS & 0.267 & 0.443 & 0 & 0 & 0 & 1 & 1 \\
\hline \multicolumn{8}{|c|}{ Panel B: Determinants and Control Variables } \\
\hline $\mathrm{VC}$ & 0.722 & 0.448 & 0 & 0 & 1 & 1 & 1 \\
\hline HiTech_NonBio & 0.355 & 0.479 & 0 & 0 & 0 & 1 & 1 \\
\hline HiTech_Bio & 0.330 & 0.471 & 0 & 0 & 0 & 1 & 1 \\
\hline Bank & 0.123 & 0.329 & 0 & 0 & 0 & 0 & 1 \\
\hline Log_AT & 4.052 & 1.468 & -0.237 & 3.184 & 3.932 & 4.728 & 9.402 \\
\hline Log_REVT & 3.306 & 1.909 & 0.000 & 2.026 & 3.729 & 4.573 & 8.138 \\
\hline ROA & -0.344 & 0.753 & -6.942 & -0.520 & -0.103 & 0.046 & 0.685 \\
\hline RDAD_Exp & 0.286 & 0.299 & 0.000 & 0.026 & 0.181 & 0.498 & 1.293 \\
\hline ProdMktFluid & 9.708 & 4.162 & 2.315 & 6.559 & 8.973 & 12.320 & 25.102 \\
\hline New_FIN & 0.310 & 0.464 & -0.216 & 0.000 & 0.071 & 0.519 & 2.431 \\
\hline Big4 & 0.810 & 0.392 & 0 & 1 & 1 & 1 & 1 \\
\hline DualClass & 0.067 & 0.250 & 0 & 0 & 0 & 0 & 1 \\
\hline Log_Age & 2.276 & 0.663 & 0.000 & 1.946 & 2.197 & 2.639 & 4.812 \\
\hline TopUW & 0.301 & 0.459 & 0 & 0 & 0 & 1 & 1 \\
\hline Log_Media_PreIPO & 0.892 & 0.577 & 0.000 & 0.693 & 1.099 & 1.099 & 3.367 \\
\hline NasdaqRET_File & 0.035 & 0.076 & -0.327 & -0.008 & 0.036 & 0.073 & 0.295 \\
\hline NasdaqRET_90 & 0.045 & 0.069 & -0.161 & 0.006 & 0.048 & 0.089 & 0.384 \\
\hline IPOCount_90 & 56.060 & 17.813 & 4 & 43 & 57 & 66 & 106 \\
\hline Exch_NYSE & 0.227 & 0.419 & 0 & 0 & 0 & 0 & 1 \\
\hline \multicolumn{8}{|c|}{ Panel C: IPO Outcome Variables } \\
\hline Log_EDGAR & 8.939 & 0.767 & 1.946 & 8.583 & 8.989 & 9.370 & 12.333 \\
\hline Underpricing & 15.163 & 23.034 & -29.532 & -0.271 & 9.416 & 24.721 & 207.674 \\
\hline Revision & -6.116 & 23.361 & -73.333 & -21.739 & -3.704 & 9.091 & 116.667 \\
\hline BASpread_1M & 0.870 & 0.648 & 0.087 & 0.430 & 0.691 & 1.124 & 5.656 \\
\hline Std_ARET1M & 0.033 & 0.017 & 0.006 & 0.021 & 0.029 & 0.041 & 0.148 \\
\hline Log_Media_1Y & 3.706 & 0.953 & 0.000 & 3.434 & 3.807 & 4.190 & 5.403 \\
\hline Analyst_Count & 6.831 & 4.448 & 0 & 4 & 6 & 9 & 33 \\
\hline Num_InstOwn>1\% & 7.262 & 5.196 & 0 & 4 & 7 & 10 & 33 \\
\hline IO_AvgStake & 1.032 & 0.826 & 0.001 & 0.490 & 0.825 & 1.299 & 7.186 \\
\hline InstOwn & 29.564 & 21.207 & 0.001 & 15.622 & 25.899 & 38.603 & 100.000 \\
\hline Retain & 0.705 & 0.152 & 0.000 & 0.662 & 0.738 & 0.792 & 0.964 \\
\hline Wealth_Reval & 83.711 & 472.034 & -455 & -40 & 1 & 97 & 8,444 \\
\hline Money_Left & 19.611 & 39.741 & -63 & 0 & 6 & 25 & 418 \\
\hline Wealth_Diff (rank) & 0.500 & 0.289 & 0.000 & 0.250 & 0.500 & 0.750 & 1.000 \\
\hline
\end{tabular}


Table 3

Press release categories and duration surrounding the Securities Offering Reform (SOR)

Properties of the press releases issued by the full sample of IPO firms in the 12 months prior to the filing of their IPO prospectus. Press releases are obtained from Ravenpack. Also reported are properties of the press releases for the sample of 99 (89) IPOs issuing press releases in the Pre(Post-) Securities Offering Reform (SOR) period. Pre-SOR covers IPOs with a filing date between January 1, 2004 and March 1, 2006. Post-SOR covers IPOs with a filing date between March 2, 2006 and March 1, 2008. The classification of press releases relies on the "group" field as defined by Ravenpack in its Version 4.0.

\begin{tabular}{|c|c|c|c|c|c|}
\hline Press Release Category/Group & $\begin{array}{c}\text { Full Sample: } \\
\text { Frequency }\end{array}$ & $\begin{array}{c}\text { Full Sample: } \\
\% \text { of Total }\end{array}$ & $\begin{array}{l}\text { Pre-SOR: } \\
\% \text { of Total }\end{array}$ & $\begin{array}{l}\text { Post-SOR: } \\
\text { \% of Total }\end{array}$ & $\begin{array}{c}\text { Difference: } \\
\text { Post - Pre }\end{array}$ \\
\hline Earnings / Revenues & 89 & $2.7 \%$ & $8.6 \%$ & $1.3 \%$ & $-7.3 \%$ \\
\hline Equity Actions & 696 & $21.1 \%$ & $23.7 \%$ & $15.5 \%$ & $-8.3 \%$ \\
\hline Labor Issues & 558 & $16.9 \%$ & $12.4 \%$ & $22.7 \%$ & $10.3 \%$ \\
\hline Marketing: Conference Participation & 144 & $4.4 \%$ & $1.7 \%$ & $4.7 \%$ & $3.0 \%$ \\
\hline Products/Services & 1,181 & $35.7 \%$ & $30.9 \%$ & $38.0 \%$ & $7.1 \%$ \\
\hline All remaining categories & 638 & $19.3 \%$ & $22.6 \%$ & $17.8 \%$ & $-4.8 \%$ \\
\hline \multicolumn{2}{|l|}{ IPOs issuing press releases } & 384 & 99 & 89 & \\
\hline \multicolumn{2}{|l|}{ Total \# of press releases issued } & 3,306 & 695 & 847 & 152 \\
\hline \multicolumn{2}{|c|}{ Percentage of firms issuing press releases } & $67.5 \%$ & $55.3 \%$ & $67.9 \%$ & $12.6 \% *$ \\
\hline \multicolumn{2}{|c|}{ Weighted average \# of days pre-prospectus } & 133 & 97 & 146 & $49 * * *$ \\
\hline
\end{tabular}


Table 4

\section{Pre-IPO information acquisition and pre-prospectus disclosure}

Results for models explaining pre-IPO information acquisition by prospective investors measured by the natural $\log$ of the number of searches for regulatory documents on the Security and Exchange Commission's EDGAR site during the filing period ending with the IPO offering date ( $\left.\log _{-} E D G A R\right)$. Results in Panel A (B) are based on OLS (weighted ordinary least squares models where weights are specified for the control sample of observations using entropy balancing; see Table B.2 of Appendix B for evidence of covariate balance after applying entropy balancing). The independent variables of interest are an indicator variable for whether the firm attends an investor conference (IConf) and the natural $\log$ of the number of press releases issued $\left(\log _{-} P R\right)$ by the firm in the 12-month period prior to the filing of its IPO prospectus. All models include IPO-level controls (see Eq. [1] in the text) along with indicators for the primary sector in which the IPO firm operates, the year of the offering, and the exchange on which the IPO is listed (indicators suppressed for presentation). Standard errors clustered by calendar quarter are presented in parentheses below the coefficients. $* * *$, and $* * *$ denote two-tailed p-values significant at a $10 \%, 5 \%$, and $1 \%$ level, respectively. See Appendix A for detailed variable definitions.

\begin{tabular}{|c|c|c|c|c|}
\hline \multirow{2}{*}{$\begin{array}{l}\text { Dep. Variable } \\
\text { Model }\end{array}$} & \multicolumn{4}{|c|}{ Log_EDGAR } \\
\hline & (1) & $(2)$ & (3) & $(4)$ \\
\hline \multicolumn{5}{|l|}{ Panel A: OLS models } \\
\hline IConf & $\begin{array}{c}0.125 \\
(1.522)\end{array}$ & & $\begin{array}{c}0.067 \\
(0.785)\end{array}$ & $\begin{array}{c}0.060 \\
(0.755)\end{array}$ \\
\hline Log_PR & & $\begin{array}{c}0.108 * * * \\
(3.568)\end{array}$ & $\begin{array}{c}0.102 * * * \\
(3.021)\end{array}$ & $\begin{array}{c}0.117 * * * \\
(3.924)\end{array}$ \\
\hline PreSOR*Log_PR & & & & $\begin{array}{c}-0.054 \\
(-0.904)\end{array}$ \\
\hline ProdMktFluid & $\begin{array}{c}0.016 \\
(1.279)\end{array}$ & $\begin{array}{c}0.014 \\
(1.127)\end{array}$ & $\begin{array}{c}0.013 \\
(1.058)\end{array}$ & $\begin{array}{c}0.013 \\
(1.071)\end{array}$ \\
\hline DualClass & $\begin{array}{c}0.350 * * * \\
(3.507)\end{array}$ & $\begin{array}{c}0.361 * * * \\
(3.520)\end{array}$ & $\begin{array}{c}0.363 * * * \\
(3.562)\end{array}$ & $\begin{array}{c}0.360 * * * \\
(3.561)\end{array}$ \\
\hline Log_AT & $\begin{array}{c}0.077 * * \\
(2.273)\end{array}$ & $\begin{array}{l}0.072 * * \\
(2.088)\end{array}$ & $\begin{array}{l}0.072 * * \\
(2.078)\end{array}$ & $\begin{array}{c}0.073 * * \\
(2.101)\end{array}$ \\
\hline Log_REVT & $\begin{array}{c}0.050 \\
(1.476)\end{array}$ & $\begin{array}{c}0.041 \\
(1.241)\end{array}$ & $\begin{array}{c}0.042 \\
(1.274)\end{array}$ & $\begin{array}{l}0.041 \\
(1.257)\end{array}$ \\
\hline ROA & $\begin{array}{c}-0.025 \\
(-0.683)\end{array}$ & $\begin{array}{c}-0.031 \\
(-0.831)\end{array}$ & $\begin{array}{c}-0.028 \\
(-0.769)\end{array}$ & $\begin{array}{c}-0.030 \\
(-0.818)\end{array}$ \\
\hline RDAD_Exp & $\begin{array}{c}0.059 \\
(0.317)\end{array}$ & $\begin{array}{c}0.019 \\
(0.108)\end{array}$ & $\begin{array}{c}0.014 \\
(0.076)\end{array}$ & $\begin{array}{c}0.007 \\
(0.037)\end{array}$ \\
\hline New_FIN & $\begin{array}{c}0.080 \\
(1.476)\end{array}$ & $\begin{array}{c}0.054 \\
(1.042)\end{array}$ & $\begin{array}{c}0.055 \\
(1.061)\end{array}$ & $\begin{array}{l}0.052 \\
(1.021)\end{array}$ \\
\hline Big4 & $\begin{array}{c}0.023 \\
(0.210)\end{array}$ & $\begin{array}{c}0.012 \\
(0.114)\end{array}$ & $\begin{array}{c}0.008 \\
(0.073)\end{array}$ & $\begin{array}{l}0.008 \\
(0.071)\end{array}$ \\
\hline $\mathrm{VC}$ & $\begin{array}{c}0.198 * * \\
(2.381)\end{array}$ & $\begin{array}{l}0.152 * \\
(1.925)\end{array}$ & $\begin{array}{l}0.154^{*} \\
(1.955)\end{array}$ & $\begin{array}{l}0.156^{*} \\
(1.979)\end{array}$ \\
\hline TopUW & $\begin{array}{c}0.219^{* * *} \\
(3.357)\end{array}$ & $\begin{array}{c}0.206^{* * *} \\
(3.200)\end{array}$ & $\begin{array}{c}0.207 * * * \\
(3.211)\end{array}$ & $\begin{array}{c}0.207 * * * \\
(3.179)\end{array}$ \\
\hline NasdaqRET_90 & $\begin{array}{c}-0.203 \\
(-0.454)\end{array}$ & $\begin{array}{c}-0.228 \\
(-0.496)\end{array}$ & $\begin{array}{c}-0.226 \\
(-0.500)\end{array}$ & $\begin{array}{c}-0.246 \\
(-0.543)\end{array}$ \\
\hline IPOCount_90 & $\begin{array}{c}0.002 \\
(1.268)\end{array}$ & $\begin{array}{c}0.002 \\
(1.091)\end{array}$ & $\begin{array}{c}0.002 \\
(1.144)\end{array}$ & $\begin{array}{c}0.002 \\
(1.058)\end{array}$ \\
\hline Log_Age & $\begin{array}{c}-0.068 \\
(-0.973)\end{array}$ & $\begin{array}{c}-0.068 \\
(-0.954)\end{array}$ & $\begin{array}{c}-0.068 \\
(-0.959)\end{array}$ & $\begin{array}{c}-0.069 \\
(-0.973)\end{array}$ \\
\hline ProdMktFluid & $\begin{array}{c}0.016 \\
(1.279)\end{array}$ & $\begin{array}{c}0.014 \\
(1.127)\end{array}$ & $\begin{array}{c}0.013 \\
(1.058)\end{array}$ & $\begin{array}{l}0.013 \\
(1.071)\end{array}$ \\
\hline DualClass & $0.350 * * *$ & $0.361 * * *$ & $0.363 * * *$ & $0.360 * * *$ \\
\hline
\end{tabular}




\begin{tabular}{|c|c|c|c|c|}
\hline \multirow{3}{*}{ Log_AT } & (3.507) & $(3.520)$ & $(3.562)$ & $(3.561)$ \\
\hline & $0.077 * *$ & $0.072 * *$ & $0.072 * *$ & $0.073 * *$ \\
\hline & $(2.273)$ & (2.088) & (2.078) & (2.101) \\
\hline \multirow[t]{2}{*}{ Log_REVT } & 0.050 & 0.041 & 0.042 & 0.041 \\
\hline & (1.476) & $(1.241)$ & (1.274) & (1.257) \\
\hline \multirow{2}{*}{ ROA } & -0.025 & -0.031 & -0.028 & -0.030 \\
\hline & $(-0.683)$ & $(-0.831)$ & $(-0.769)$ & $(-0.818)$ \\
\hline RDAD_Exp & $\begin{array}{c}0.059 \\
(0.317)\end{array}$ & $\begin{array}{c}0.019 \\
(0.108)\end{array}$ & $\begin{array}{c}0.014 \\
(0.076)\end{array}$ & $\begin{array}{c}0.007 \\
(0.037)\end{array}$ \\
\hline Fixed Effects & $\begin{array}{l}\text { Sector, Year, } \\
\text { Exchange }\end{array}$ & $\begin{array}{l}\text { Sector, Year, } \\
\text { Exchange }\end{array}$ & $\begin{array}{l}\text { Sector, Year, } \\
\text { Exchange }\end{array}$ & $\begin{array}{l}\text { Sector, Year, } \\
\text { Exchange }\end{array}$ \\
\hline Observations & 569 & 569 & 569 & 569 \\
\hline Adjusted $\mathrm{R}^{2}$ & 0.350 & 0.360 & 0.360 & 0.359 \\
\hline \multicolumn{5}{|c|}{ Panel B: Entropy-balanced models } \\
\hline IConf & $\begin{array}{c}0.213^{* *} \\
(2.612)\end{array}$ & & & \\
\hline Log_PR & & $\begin{array}{l}0.046^{*} \\
(2.012)\end{array}$ & $\begin{array}{c}0.074 * * * \\
(3.276)\end{array}$ & \\
\hline PreSOR*Log_PR & & & $\begin{array}{l}-0.106^{*} \\
(-1.722)\end{array}$ & \\
\hline $\begin{array}{l}\text { Additional Controls } \\
\text { Included? }\end{array}$ & Yes & Yes & Yes & \\
\hline Fixed Effects & $\begin{array}{l}\text { Sector, Year, } \\
\text { Exchange }\end{array}$ & $\begin{array}{l}\text { Sector, Year, } \\
\text { Exchange }\end{array}$ & $\begin{array}{l}\text { Sector, Year, } \\
\text { Exchange }\end{array}$ & \\
\hline Observations & 569 & 569 & 569 & \\
\hline
\end{tabular}


Table 5

\section{IPO pricing and pre-prospectus disclosure}

Results for models explaining IPO price changes measured as filing period price revisions between the initial file price and the final price set for the IPO (Revision) and IPO underpricing measured as the first-day percentage change in price less the valueweighted return to the CRSP market index (Underpricing). Results in Panel A (B) are based on OLS (weighted ordinary least squares models where weights are specified for the control sample of observations using entropy balancing; see Table B.2 of Appendix B for evidence of covariate balance after applying entropy balancing). The independent variables of interest are an indicator variable for whether the firm attends an investor conference (IConf) and the natural log of the number of press releases issued $\left(\log _{-} P R\right)$ by the firm in the 12-month period prior to the filing of its IPO prospectus. All models include IPO-level controls (see Eq. [1] in the text) along with indicators for the primary sector in which the IPO firm operates, the year of the offering, and the exchange on which the IPO is listed (indicators suppressed for presentation). Models where Revision (Underpricing) is the dependent variable include an additional control for the filing period return to the NASDAQ index, NasdaqRET_File (filing period price revision, Revision). Standard errors clustered by calendar quarter are presented in parentheses below the coefficients. $*, * *$, and $* * *$ denote two-tailed p-values significant at a $10 \%, 5 \%$, and $1 \%$ level, respectively. See Appendix A for detailed variable definitions.

\begin{tabular}{|c|c|c|c|c|c|c|c|c|}
\hline \multirow{2}{*}{$\begin{array}{l}\text { Dep. Variable } \\
\text { Model }\end{array}$} & \multicolumn{4}{|c|}{ Revision } & \multicolumn{4}{|c|}{ Underpricing } \\
\hline & (1) & (2) & (3) & (4) & (5) & (6) & (7) & (8) \\
\hline \multicolumn{9}{|l|}{ Panel A: OLS models } \\
\hline IConf & $\begin{array}{c}7.913 * * * \\
(3.789)\end{array}$ & & $\begin{array}{c}6.094 * * * \\
(2.767)\end{array}$ & $\begin{array}{l}5.528^{* *} \\
(2.471)\end{array}$ & $\begin{array}{c}6.536 \\
(1.454)\end{array}$ & & $\begin{array}{c}5.230 \\
(1.120)\end{array}$ & $\begin{array}{c}4.871 \\
(1.039)\end{array}$ \\
\hline Log_PR & & $\begin{array}{c}3.768 * * * \\
(4.050)\end{array}$ & $\begin{array}{c}3.220 * * * \\
(3.310)\end{array}$ & $\begin{array}{c}4.390 * * * \\
(3.581)\end{array}$ & & $\begin{array}{c}2.910 * * \\
(2.433)\end{array}$ & $\begin{array}{l}2.467 * \\
(1.989)\end{array}$ & $\begin{array}{l}3.292 * * \\
(2.257)\end{array}$ \\
\hline PreSOR*Log_PR & & & & $\begin{array}{c}-4.194 * * * \\
(-2.954)\end{array}$ & & & & $\begin{array}{l}-2.898^{*} \\
(-1.728)\end{array}$ \\
\hline ProdMktFluid & $\begin{array}{c}-1.257 * * * \\
(-3.320)\end{array}$ & $\begin{array}{c}-1.274 * * * \\
(-3.214)\end{array}$ & $\begin{array}{c}-1.353 * * * \\
(-3.458)\end{array}$ & $\begin{array}{c}-1.321 * * * \\
(-3.310)\end{array}$ & $\begin{array}{c}0.273 \\
(0.983)\end{array}$ & $\begin{array}{c}0.263 \\
(1.027)\end{array}$ & $\begin{array}{c}0.186 \\
(0.700)\end{array}$ & $\begin{array}{c}0.200 \\
(0.750)\end{array}$ \\
\hline DualClass & $\begin{array}{c}0.880 \\
(0.297)\end{array}$ & $\begin{array}{l}1.148 \\
(0.401)\end{array}$ & $\begin{array}{l}1.306 \\
(0.453)\end{array}$ & $\begin{array}{c}1.106 \\
(0.389)\end{array}$ & $\begin{array}{c}2.763 \\
(1.006)\end{array}$ & $\begin{array}{c}2.940 \\
(1.143)\end{array}$ & $\begin{array}{c}3.093 \\
(1.185)\end{array}$ & $\begin{array}{c}2.945 \\
(1.099)\end{array}$ \\
\hline Log_AT & $\begin{array}{c}0.381 \\
(0.366)\end{array}$ & $\begin{array}{c}0.248 \\
(0.227)\end{array}$ & $\begin{array}{c}0.217 \\
(0.206)\end{array}$ & $\begin{array}{c}0.273 \\
(0.260)\end{array}$ & $\begin{array}{c}-0.683 \\
(-0.523)\end{array}$ & $\begin{array}{c}-0.783 \\
(-0.606)\end{array}$ & $\begin{array}{c}-0.807 \\
(-0.621)\end{array}$ & $\begin{array}{c}-0.769 \\
(-0.596)\end{array}$ \\
\hline Log_REVT & $\begin{array}{l}2.093^{* *} \\
(2.498)\end{array}$ & $\begin{array}{l}1.772 * * \\
(2.071)\end{array}$ & $\begin{array}{l}1.852 * * \\
(2.219)\end{array}$ & $\begin{array}{l}1.805^{* *} \\
(2.203)\end{array}$ & $\begin{array}{c}0.817 \\
(0.491)\end{array}$ & $\begin{array}{c}0.571 \\
(0.352)\end{array}$ & $\begin{array}{c}0.652 \\
(0.406)\end{array}$ & $\begin{array}{c}0.629 \\
(0.393)\end{array}$ \\
\hline ROA & $\begin{array}{c}0.539 \\
(0.597)\end{array}$ & $\begin{array}{c}0.231 \\
(0.242)\end{array}$ & $\begin{array}{c}0.451 \\
(0.491)\end{array}$ & $\begin{array}{c}0.314 \\
(0.341)\end{array}$ & $\begin{array}{c}2.653 \\
(1.684)\end{array}$ & $\begin{array}{c}2.397 \\
(1.502)\end{array}$ & $\begin{array}{c}2.589 \\
(1.593)\end{array}$ & $\begin{array}{c}2.493 \\
(1.522)\end{array}$ \\
\hline RDAD_Exp & $\begin{array}{l}1.115 \\
(0.170)\end{array}$ & $\begin{array}{c}0.205 \\
(0.031)\end{array}$ & $\begin{array}{c}-0.321 \\
(-0.049)\end{array}$ & $\begin{array}{c}-0.881 \\
(-0.136)\end{array}$ & $\begin{array}{c}2.361 \\
(0.419)\end{array}$ & $\begin{array}{c}1.732 \\
(0.343)\end{array}$ & $\begin{array}{c}1.274 \\
(0.235)\end{array}$ & $\begin{array}{c}0.898 \\
(0.166)\end{array}$ \\
\hline New_FIN & $\begin{array}{c}-0.689 \\
(-0.309)\end{array}$ & $\begin{array}{c}-1.565 \\
(-0.662)\end{array}$ & $\begin{array}{c}-1.458 \\
(-0.628)\end{array}$ & $\begin{array}{c}-1.698 \\
(-0.739)\end{array}$ & $\begin{array}{c}1.384 \\
(0.460)\end{array}$ & $\begin{array}{c}0.692 \\
(0.225)\end{array}$ & $\begin{array}{c}0.777 \\
(0.249)\end{array}$ & $\begin{array}{c}0.593 \\
(0.188)\end{array}$ \\
\hline Big4 & $\begin{array}{c}-0.066 \\
(-0.023)\end{array}$ & $\begin{array}{c}-0.172 \\
(-0.062)\end{array}$ & $\begin{array}{c}-0.547 \\
(-0.194)\end{array}$ & $\begin{array}{c}-0.567 \\
(-0.199)\end{array}$ & $\begin{array}{c}-3.113 \\
(-1.627)\end{array}$ & $\begin{array}{c}-3.153 \\
(-1.486)\end{array}$ & $\begin{array}{l}-3.481^{*} \\
(-1.740)\end{array}$ & $\begin{array}{l}-3.490^{*} \\
(-1.729)\end{array}$ \\
\hline $\mathrm{VC}$ & $\begin{array}{l}1.642 \\
(0.619)\end{array}$ & $\begin{array}{c}0.060 \\
(0.021)\end{array}$ & $\begin{array}{c}0.268 \\
(0.092)\end{array}$ & $\begin{array}{c}0.421 \\
(0.147)\end{array}$ & $\begin{array}{c}9.492 * * * \\
(3.907)\end{array}$ & $\begin{array}{c}8.261 * * * \\
(3.325)\end{array}$ & $\begin{array}{c}8.446 * * * \\
(3.439)\end{array}$ & $\begin{array}{c}8.539 * * * \\
(3.407)\end{array}$ \\
\hline TopUW & $\begin{array}{c}6.510 * * * \\
(2.737)\end{array}$ & $\begin{array}{c}6.048 * * \\
(2.632)\end{array}$ & $\begin{array}{c}6.110 * * \\
(2.674)\end{array}$ & $\begin{array}{c}6.076^{* *} \\
(2.689)\end{array}$ & $\begin{array}{c}5.352 * * \\
(2.559)\end{array}$ & $\begin{array}{c}5.028 * * \\
(2.432)\end{array}$ & $\begin{array}{c}5.121 * * \\
(2.458)\end{array}$ & $\begin{array}{c}5.139 * * \\
(2.484)\end{array}$ \\
\hline NasdaqRET_[File, 90] & $\begin{array}{l}22.106 \\
(1.661)\end{array}$ & $\begin{array}{c}23.132 * \\
(1.778)\end{array}$ & $\begin{array}{c}22.915^{*} \\
(1.790)\end{array}$ & $\begin{array}{c}23.362 * \\
(1.819)\end{array}$ & $\begin{array}{l}16.503 \\
(1.496)\end{array}$ & $\begin{array}{l}15.953 \\
(1.492)\end{array}$ & $\begin{array}{l}16.483 \\
(1.489)\end{array}$ & $\begin{array}{l}15.701 \\
(1.408)\end{array}$ \\
\hline IPOCount_90 & $\begin{array}{c}-0.049 \\
(-0.539)\end{array}$ & $\begin{array}{c}-0.061 \\
(-0.680)\end{array}$ & $\begin{array}{c}-0.054 \\
(-0.611)\end{array}$ & $\begin{array}{c}-0.067 \\
(-0.786)\end{array}$ & $\begin{array}{c}-0.040 \\
(-0.903)\end{array}$ & $\begin{array}{c}-0.051 \\
(-1.073)\end{array}$ & $\begin{array}{c}-0.045 \\
(-0.917)\end{array}$ & $\begin{array}{c}-0.055 \\
(-1.071)\end{array}$ \\
\hline Log_Age & $\begin{array}{c}-2.117 \\
(-1.208)\end{array}$ & $\begin{array}{c}-2.092 \\
(-1.175)\end{array}$ & $\begin{array}{c}-2.145 \\
(-1.208)\end{array}$ & $\begin{array}{c}-2.172 \\
(-1.247)\end{array}$ & $\begin{array}{c}0.516 \\
(0.359)\end{array}$ & $\begin{array}{c}0.539 \\
(0.366)\end{array}$ & $\begin{array}{c}0.476 \\
(0.330)\end{array}$ & $\begin{array}{c}0.452 \\
(0.312)\end{array}$ \\
\hline
\end{tabular}




\begin{tabular}{|c|c|c|c|c|c|c|c|c|}
\hline Revision & & & & & $0.458 * * *$ & $0.454 * * *$ & $0.447 * * *$ & $0.442 * * *$ \\
\hline $\begin{array}{l}\text { Fixed effects } \\
\text { Observations } \\
\text { Adjusted } \mathrm{R}^{2}\end{array}$ & $\begin{array}{c}\text { Sector, } \\
\text { Year, } \\
\text { Exchange } \\
569 \\
0.191\end{array}$ & $\begin{array}{c}\text { Sector, } \\
\text { Year, } \\
\text { Exchange } \\
569 \\
0.196\end{array}$ & $\begin{array}{c}\text { Sector, } \\
\text { Year, } \\
\text { Exchange } \\
569 \\
0.202\end{array}$ & $\begin{array}{c}\text { Sector, } \\
\text { Year, } \\
\text { Exchange } \\
569 \\
0.207\end{array}$ & $\begin{array}{c}\text { Sector, } \\
\text { Year, } \\
\text { Exchange } \\
569 \\
0.297\end{array}$ & $\begin{array}{c}\text { Sector, } \\
\text { Year, } \\
\text { Exchange } \\
569 \\
0.299\end{array}$ & $\begin{array}{c}\text { Sector, } \\
\text { Year, } \\
\text { Exchange } \\
569 \\
0.302\end{array}$ & $\begin{array}{c}\text { Sector, } \\
\text { Year, } \\
\text { Exchange } \\
569 \\
0.304\end{array}$ \\
\hline \multicolumn{9}{|c|}{ Panel B: Entropy-balanced models } \\
\hline IConf & $\begin{array}{c}7.513 * * * \\
(3.337)\end{array}$ & & & & $\begin{array}{l}5.364^{*} \\
(1.686)\end{array}$ & & & \\
\hline $\begin{array}{l}\text { Log_PR } \\
\text { PreSOR*Log_PR }\end{array}$ & & $\begin{array}{c}3.478 * * * \\
(3.170)\end{array}$ & $\begin{array}{c}4.757 * * * \\
(3.763) \\
-5.020 * * \\
(-2.667)\end{array}$ & & & $\begin{array}{c}2.684 * * \\
(2.186)\end{array}$ & $\begin{array}{c}3.628 * * \\
(2.701) \\
-3.557 * * \\
(-2.099)\end{array}$ & \\
\hline $\begin{array}{l}\text { Additional Controls } \\
\text { Included? }\end{array}$ & Yes & Yes & Yes & & Yes & Yes & Yes & \\
\hline $\begin{array}{l}\text { Fixed effects } \\
\text { Observations }\end{array}$ & $\begin{array}{c}\text { Sector, } \\
\text { Year, } \\
\text { Exchange } \\
569\end{array}$ & $\begin{array}{l}\text { Sector, } \\
\text { Year, } \\
\text { Exchange } \\
569\end{array}$ & $\begin{array}{c}\text { Sector, } \\
\text { Year, } \\
\text { Exchange } \\
569\end{array}$ & & $\begin{array}{c}\text { Sector, } \\
\text { Year, } \\
\text { Exchange } \\
569\end{array}$ & $\begin{array}{c}\text { Sector, } \\
\text { Year, } \\
\text { Exchange } \\
569\end{array}$ & $\begin{array}{c}\text { Sector, } \\
\text { Year, } \\
\text { Exchange } \\
569\end{array}$ & \\
\hline
\end{tabular}


Table 6

IPO ownership and pre-prospectus disclosure

Results for models explaining the count of institutional owners holding more than $1 \%$ of the IPO firms' equity as of the first available reporting date in Thomson Reuters during the 12-month period following the IPO (Num_InstOwn>1\%) and the average percent ownership for each institutional owner listed on the first available reporting date in Thomson Reuters during the post-IPO period (IO_AvgStake). Tests where Num_InstOwn>1\% is the dependent variable rely on a negative binomial regression model designed for count data following the recommendation by Rock, Sedo, and Willenborg (2000). Results in Panel A (B) are based on unweighted negative binomial and OLS regression models (weighted regression models where weights are specified for the control sample of observations using entropy balancing; see Table B.2 of Appendix B for evidence of covariate balance after applying entropy balancing). The independent variables of interest are an indicator variable for whether the firm attends an investor conference (IConf) and the natural $\log$ of the number of press releases issued ( $\left.\log _{-} P R\right)$ by the firm in the 12-month period prior to the filing of its IPO prospectus. All models include IPO-level controls (see Eq. [1] in the text) along with indicators for the primary sector in which the IPO firm operates, the year of the offering, and the exchange on which the IPO is listed (indicators suppressed for presentation). Standard errors clustered by calendar quarter are presented in parentheses below the coefficients. *, **, and $* * *$ denote two-tailed p-values significant at a 10\%, 5\%, and $1 \%$ level, respectively. See Appendix A for detailed variable definitions.

\begin{tabular}{|c|c|c|c|c|c|c|c|c|}
\hline \multirow{2}{*}{$\begin{array}{l}\text { Dep. Variable } \\
\text { (Regression Model) } \\
\text { Model }\end{array}$} & \multicolumn{4}{|c|}{$\begin{array}{l}\text { Num_InstOwn>1\% } \\
\text { (Negative Binomial) }\end{array}$} & \multicolumn{4}{|c|}{$\begin{array}{c}\text { IO_AvgStake } \\
\text { (OLS) }\end{array}$} \\
\hline & (1) & $(2)$ & (3) & $(4)$ & (5) & (6) & (7) & (8) \\
\hline \multicolumn{9}{|c|}{ Panel A: Unweighted regression models } \\
\hline IConf & $\begin{array}{c}-0.073 \\
(-0.854)\end{array}$ & & $\begin{array}{c}-0.050 \\
(-0.603)\end{array}$ & $\begin{array}{c}-0.037 \\
(-0.450)\end{array}$ & $\begin{array}{c}-0.132 \\
(-1.637)\end{array}$ & & $\begin{array}{c}-0.095 \\
(-1.250)\end{array}$ & $\begin{array}{c}-0.078 \\
(-1.051)\end{array}$ \\
\hline Log_PR & & $\begin{array}{l}-0.046^{*} \\
(-1.836)\end{array}$ & $\begin{array}{l}-0.041 * \\
(-1.797)\end{array}$ & $\begin{array}{c}-0.067 * * \\
(-2.338)\end{array}$ & & $\begin{array}{l}-0.074 * \\
(-1.977)\end{array}$ & $\begin{array}{l}-0.066^{*} \\
(-1.812)\end{array}$ & $\begin{array}{l}-0.100 * * \\
(-2.527)\end{array}$ \\
\hline PreSOR*Log_PR & & & & $\begin{array}{l}0.087 * * \\
(2.293)\end{array}$ & & & & $\begin{array}{c}0.123 \\
(1.595)\end{array}$ \\
\hline ProdMktFluid & $\begin{array}{c}0.011 \\
(1.488)\end{array}$ & $\begin{array}{l}0.012 * \\
(1.650)\end{array}$ & $\begin{array}{c}0.012 \\
(1.644)\end{array}$ & $\begin{array}{c}0.012 \\
(1.604)\end{array}$ & $\begin{array}{c}0.021 \\
(1.466)\end{array}$ & $\begin{array}{c}0.022 \\
(1.451)\end{array}$ & $\begin{array}{c}0.023 \\
(1.540)\end{array}$ & $\begin{array}{c}0.022 \\
(1.465)\end{array}$ \\
\hline DualClass & $\begin{array}{l}-0.128^{*} \\
(-1.806)\end{array}$ & $\begin{array}{l}-0.129 * \\
(-1.828)\end{array}$ & $\begin{array}{l}-0.130^{*} \\
(-1.823)\end{array}$ & $\begin{array}{l}-0.125^{*} \\
(-1.719)\end{array}$ & $\begin{array}{c}0.574 * * * \\
(5.243)\end{array}$ & $\begin{array}{c}0.568 * * * \\
(5.275)\end{array}$ & $\begin{array}{c}0.566 * * * \\
(5.212)\end{array}$ & $\begin{array}{c}0.572 * * * \\
(5.321)\end{array}$ \\
\hline Log_AT & $\begin{array}{l}-0.009 \\
(-0.457)\end{array}$ & $\begin{array}{c}-0.009 \\
(-0.445)\end{array}$ & $\begin{array}{l}-0.008 \\
(-0.425)\end{array}$ & $\begin{array}{l}-0.010 \\
(-0.488)\end{array}$ & $\begin{array}{c}-0.104 * * * \\
(-3.143)\end{array}$ & $\begin{array}{c}-0.101 * * * \\
(-2.965)\end{array}$ & $\begin{array}{c}-0.101 * * * \\
(-2.979)\end{array}$ & $\begin{array}{c}-0.102 * * * \\
(-3.025)\end{array}$ \\
\hline Log_REVT & $\begin{array}{c}0.013 \\
(0.658)\end{array}$ & $\begin{array}{c}0.018 \\
(0.900)\end{array}$ & $\begin{array}{c}0.017 \\
(0.863)\end{array}$ & $\begin{array}{c}0.019 \\
(0.972)\end{array}$ & $\begin{array}{c}-0.107 * * * \\
(-3.228)\end{array}$ & $\begin{array}{c}-0.100 * * * \\
(-3.195)\end{array}$ & $\begin{array}{c}-0.102 * * * \\
(-3.251)\end{array}$ & $\begin{array}{c}-0.100 * * * \\
(-3.330)\end{array}$ \\
\hline ROA & $\begin{array}{c}0.006 \\
(0.367)\end{array}$ & $\begin{array}{c}0.012 \\
(0.729)\end{array}$ & $\begin{array}{c}0.009 \\
(0.520)\end{array}$ & $\begin{array}{c}0.010 \\
(0.591)\end{array}$ & $\begin{array}{l}-0.020 \\
(-0.320)\end{array}$ & $\begin{array}{l}-0.015 \\
(-0.230)\end{array}$ & $\begin{array}{l}-0.018 \\
(-0.285)\end{array}$ & $\begin{array}{l}-0.014 \\
(-0.226)\end{array}$ \\
\hline RDAD_Exp & $\begin{array}{l}-0.224 * * \\
(-1.963)\end{array}$ & $\begin{array}{l}-0.209^{*} \\
(-1.836)\end{array}$ & $\begin{array}{l}-0.205^{*} \\
(-1.764)\end{array}$ & $\begin{array}{l}-0.193^{*} \\
(-1.693)\end{array}$ & $\begin{array}{c}-0.302 \\
(-1.158)\end{array}$ & $\begin{array}{l}-0.281 \\
(-1.079)\end{array}$ & $\begin{array}{c}-0.273 \\
(-1.057)\end{array}$ & $\begin{array}{l}-0.257 \\
(-1.016)\end{array}$ \\
\hline New_FIN & $\begin{array}{l}-0.058 \\
(-1.571)\end{array}$ & $\begin{array}{c}-0.048 \\
(-1.270)\end{array}$ & $\begin{array}{c}-0.048 \\
(-1.269)\end{array}$ & $\begin{array}{l}-0.043 \\
(-1.134)\end{array}$ & $\begin{array}{c}0.002 \\
(0.029)\end{array}$ & $\begin{array}{l}0.020 \\
(0.237)\end{array}$ & $\begin{array}{c}0.018 \\
(0.219)\end{array}$ & $\begin{array}{c}0.026 \\
(0.312)\end{array}$ \\
\hline Big4 & $\begin{array}{c}0.004 \\
(0.067)\end{array}$ & $\begin{array}{c}0.009 \\
(0.180)\end{array}$ & $\begin{array}{c}0.011 \\
(0.216)\end{array}$ & $\begin{array}{c}0.013 \\
(0.247)\end{array}$ & $\begin{array}{c}0.050 \\
(0.501)\end{array}$ & $\begin{array}{c}0.054 \\
(0.539)\end{array}$ & $\begin{array}{c}0.059 \\
(0.604)\end{array}$ & $\begin{array}{c}0.060 \\
(0.595)\end{array}$ \\
\hline $\mathrm{VC}$ & $\begin{array}{c}0.064 \\
(1.119)\end{array}$ & $\begin{array}{c}0.084 \\
(1.357)\end{array}$ & $\begin{array}{c}0.082 \\
(1.345)\end{array}$ & $\begin{array}{c}0.077 \\
(1.196)\end{array}$ & $\begin{array}{c}0.026 \\
(0.256)\end{array}$ & $\begin{array}{c}0.057 \\
(0.527)\end{array}$ & $\begin{array}{c}0.054 \\
(0.502)\end{array}$ & $\begin{array}{c}0.050 \\
(0.471)\end{array}$ \\
\hline TopUW & $\begin{array}{c}-0.082 * * \\
(-2.414)\end{array}$ & $\begin{array}{c}-0.078 * * \\
(-2.301)\end{array}$ & $\begin{array}{c}-0.078 * * \\
(-2.281)\end{array}$ & $\begin{array}{c}-0.079 * * \\
(-2.393)\end{array}$ & $\begin{array}{c}-0.117 \\
(-1.583)\end{array}$ & $\begin{array}{c}-0.108 \\
(-1.476)\end{array}$ & $\begin{array}{c}-0.109 \\
(-1.481)\end{array}$ & $\begin{array}{c}-0.109 \\
(-1.450)\end{array}$ \\
\hline NasdaqRET_90 & $\begin{array}{c}0.364 \\
(1.233)\end{array}$ & $\begin{array}{c}0.360 \\
(1.275)\end{array}$ & $\begin{array}{c}0.356 \\
(1.252)\end{array}$ & $\begin{array}{c}0.402 \\
(1.365)\end{array}$ & $\begin{array}{c}-0.052 \\
(-0.082)\end{array}$ & $\begin{array}{c}-0.033 \\
(-0.053)\end{array}$ & $\begin{array}{c}-0.037 \\
(-0.058)\end{array}$ & $\begin{array}{c}0.008 \\
(0.013)\end{array}$ \\
\hline IPOCount_90 & $\begin{array}{c}-0.002 \\
(-1.159)\end{array}$ & $\begin{array}{c}-0.002 \\
(-1.162)\end{array}$ & $\begin{array}{c}-0.002 \\
(-1.181)\end{array}$ & $\begin{array}{c}-0.002 \\
(-0.972)\end{array}$ & $\begin{array}{l}0.004 * \\
(1.696)\end{array}$ & $\begin{array}{l}0.004^{*} \\
(1.862)\end{array}$ & $\begin{array}{l}0.004^{*} \\
(1.815)\end{array}$ & $\begin{array}{c}0.004 * * \\
(2.222)\end{array}$ \\
\hline
\end{tabular}




\begin{tabular}{|c|c|c|c|c|c|c|c|c|}
\hline Log_Age & $\begin{array}{l}-0.013 \\
(-0.617)\end{array}$ & $\begin{array}{l}-0.013 \\
(-0.604)\end{array}$ & $\begin{array}{l}-0.013 \\
(-0.602)\end{array}$ & $\begin{array}{l}-0.013 \\
(-0.582)\end{array}$ & $\begin{array}{c}0.183 * * \\
(2.663)\end{array}$ & $\begin{array}{c}0.182 * * \\
(2.638)\end{array}$ & $\begin{array}{c}0.183 * * \\
(2.648)\end{array}$ & $\begin{array}{c}0.184 * * \\
(2.677)\end{array}$ \\
\hline ProdMktFluid & $\begin{array}{c}0.011 \\
(1.488)\end{array}$ & $\begin{array}{l}0.012 * \\
(1.650)\end{array}$ & $\begin{array}{l}0.012 \\
(1.644)\end{array}$ & $\begin{array}{c}0.012 \\
(1.604)\end{array}$ & $\begin{array}{c}0.021 \\
(1.466)\end{array}$ & $\begin{array}{c}0.022 \\
(1.451)\end{array}$ & $\begin{array}{c}0.023 \\
(1.540)\end{array}$ & $\begin{array}{c}0.022 \\
(1.465)\end{array}$ \\
\hline DualClass & $\begin{array}{l}-0.128^{*} \\
(-1.806)\end{array}$ & $\begin{array}{l}-0.129 * \\
(-1.828)\end{array}$ & $\begin{array}{l}-0.130^{*} \\
(-1.823)\end{array}$ & $\begin{array}{l}-0.125^{*} \\
(-1.719)\end{array}$ & $\begin{array}{c}0.574 * * * \\
(5.243)\end{array}$ & $\begin{array}{c}0.568 * * * \\
(5.275)\end{array}$ & $\begin{array}{c}0.566 * * * \\
(5.212)\end{array}$ & $\begin{array}{c}0.572 * * * \\
(5.321)\end{array}$ \\
\hline InstOwn & $\begin{array}{c}0.024 * * * \\
(17.935)\end{array}$ & $\begin{array}{l}0.024 * * * \\
(17.903)\end{array}$ & $\begin{array}{c}0.024 * * * \\
(18.055)\end{array}$ & $\begin{array}{c}0.024 * * * \\
(18.854)\end{array}$ & & & & \\
\hline Fixed Effects & $\begin{array}{c}\text { Sector, } \\
\text { Year, } \\
\text { Exchange }\end{array}$ & $\begin{array}{c}\text { Sector, } \\
\text { Year, } \\
\text { Exchange }\end{array}$ & $\begin{array}{c}\text { Sector, } \\
\text { Year, } \\
\text { Exchange }\end{array}$ & $\begin{array}{c}\text { Sector, } \\
\text { Year, } \\
\text { Exchange }\end{array}$ & $\begin{array}{c}\text { Sector, } \\
\text { Year, } \\
\text { Exchange }\end{array}$ & $\begin{array}{c}\text { Sector, } \\
\text { Year, } \\
\text { Exchange }\end{array}$ & $\begin{array}{c}\text { Sector, } \\
\text { Year, } \\
\text { Exchange }\end{array}$ & $\begin{array}{c}\text { Sector, } \\
\text { Year, } \\
\text { Exchange }\end{array}$ \\
\hline Observations & 569 & 569 & 569 & 569 & 569 & 569 & 569 & 569 \\
\hline $\begin{array}{l}\text { Log-Likelihood / } \\
\text { Adjusted R } \mathrm{R}^{2}\end{array}$ & -1363 & -1362 & -1362 & -1359 & 0.126 & 0.128 & 0.128 & 0.131 \\
\hline \multicolumn{9}{|c|}{ Panel B: Entropy-balanced models } \\
\hline IConf & $\begin{array}{c}-0.077 \\
(-1.010)\end{array}$ & & & & $\begin{array}{c}-0.108 \\
(-1.313)\end{array}$ & & & \\
\hline Log_PR & & $\begin{array}{c}-0.044 \\
(-1.513)\end{array}$ & $\begin{array}{l}-0.060 * \\
(-1.694)\end{array}$ & & & $\begin{array}{c}0.021 \\
(0.577)\end{array}$ & $\begin{array}{c}-0.001 \\
(-0.033)\end{array}$ & \\
\hline PreSOR*Log_PR & & & $\begin{array}{c}0.054 \\
(1.105)\end{array}$ & & & & $\begin{array}{c}0.086 \\
(1.125)\end{array}$ & \\
\hline $\begin{array}{l}\text { Additional Controls } \\
\text { Included? }\end{array}$ & Yes & Yes & Yes & & Yes & Yes & Yes & \\
\hline Fixed effects & $\begin{array}{c}\text { Sector, } \\
\text { Year, } \\
\text { Exchange }\end{array}$ & $\begin{array}{c}\text { Sector, } \\
\text { Year, } \\
\text { Exchange }\end{array}$ & $\begin{array}{c}\text { Sector, } \\
\text { Year, } \\
\text { Exchange }\end{array}$ & & $\begin{array}{c}\text { Sector, } \\
\text { Year, } \\
\text { Exchange }\end{array}$ & $\begin{array}{l}\text { Sector, } \\
\text { Year, } \\
\text { Exchange }\end{array}$ & $\begin{array}{l}\text { Sector, } \\
\text { Year, } \\
\text { Exchange }\end{array}$ & \\
\hline Observations & 569 & 569 & 569 & & 569 & 569 & 569 & \\
\hline
\end{tabular}


Table 7

Post-IPO visibility and pre-prospectus disclosure

Results for models explaining the count of the number of unique analysts issuing earnings per share forecasts for the firm during the 12-month post-IPO period in I/B/E/S (Analyst_Count) and the natural log of the number of media articles with a novelty score of 100 and a relevance score of 100 for the IPO firm (which indicate first-release articles written specifically about the IPO firm) available via Ravenpack's Dow Jones and PR Editions during the 12-month post-IPO period (Log_Media_1Y). Tests where Analyst_Count is the dependent variable rely on a negative binomial regression model designed for count data following the recommendation by Rock, Sedo, and Willenborg (2000). Results in Panel A (B) are based on unweighted negative binomial and OLS regression models (weighted regression models where weights are specified for the control sample of observations using entropy balancing; see Table B.2 of Appendix B for evidence of covariate balance after applying entropy balancing). The independent variables of interest are an indicator variable for whether the firm attends an investor conference (IConf) and the natural log of the number of press releases issued (Log_PR) by the firm in the 12-month period prior to the filing of its IPO prospectus. All models include IPO-level controls (see Eq. [1] in the text) along with indicators for the primary sector in which the IPO firm operates, the year of the offering, and the exchange on which the IPO is listed (indicators suppressed for presentation). In addition, models where $\log _{-} M e d i a_{-} 1 Y$ is the dependent variable include an additional control for the natural log of the number of filing period media articles in Ravenpack (Log_Media_PreIPO). Standard errors clustered by calendar quarter are presented in parentheses below the coefficients. *,**, and *** denote twotailed p-values significant at a $10 \%, 5 \%$, and $1 \%$ level, respectively. See Appendix A for detailed variable definitions.

\begin{tabular}{|c|c|c|c|c|c|c|c|c|}
\hline \multirow{2}{*}{$\begin{array}{l}\text { Dep. Variable } \\
\text { (Regression Model) } \\
\text { Model }\end{array}$} & \multicolumn{4}{|c|}{$\begin{array}{c}\text { Analyst_Count } \\
\text { (Negative Binomial) }\end{array}$} & \multicolumn{4}{|c|}{$\underset{(\text { OLS })}{\log { }_{\text {Media_1Y }}}$} \\
\hline & $(1)$ & (2) & (3) & $(4)$ & $(5)$ & (6) & $(7)$ & $(8)$ \\
\hline \multicolumn{9}{|c|}{ Panel A: Unweighted regression models } \\
\hline IConf & $\begin{array}{c}0.127 \\
(1.604)\end{array}$ & & $\begin{array}{c}0.063 \\
(0.814)\end{array}$ & $\begin{array}{c}0.058 \\
(0.740)\end{array}$ & $\begin{array}{c}0.228 * * * \\
(2.890)\end{array}$ & & $\begin{array}{l}0.145^{*} \\
(1.899)\end{array}$ & $\begin{array}{c}0.156^{* *} \\
(2.029)\end{array}$ \\
\hline Log_PR & & $\begin{array}{c}0.119 * * * \\
(6.471)\end{array}$ & $\begin{array}{c}0.113 * * * \\
(5.723)\end{array}$ & $\begin{array}{c}0.129 * * * \\
(5.408)\end{array}$ & & $\begin{array}{c}0.164 * * * \\
(4.826)\end{array}$ & $\begin{array}{c}0.151 * * * \\
(4.575)\end{array}$ & $\begin{array}{c}0.129 * * * \\
(3.822)\end{array}$ \\
\hline PreSOR*Log_PR & & & & $\begin{array}{l}-0.062 \\
(-1.399)\end{array}$ & & & & $\begin{array}{c}0.085 \\
(1.068)\end{array}$ \\
\hline ProdMktFluid & $\begin{array}{c}0.014 \\
(1.271)\end{array}$ & $\begin{array}{c}0.010 \\
(0.977)\end{array}$ & $\begin{array}{c}0.010 \\
(0.886)\end{array}$ & $\begin{array}{l}0.010 \\
(0.914)\end{array}$ & $\begin{array}{l}-0.014 \\
(-1.084)\end{array}$ & $\begin{array}{l}-0.016 \\
(-1.151)\end{array}$ & $\begin{array}{c}-0.018 \\
(-1.288)\end{array}$ & $\begin{array}{l}-0.018 \\
(-1.326)\end{array}$ \\
\hline DualClass & $\begin{array}{l}0.175^{*} \\
(1.886)\end{array}$ & $\begin{array}{l}0.193 * * \\
(2.272)\end{array}$ & $\begin{array}{l}0.192 * * \\
(2.295)\end{array}$ & $\begin{array}{c}0.186 * * \\
(2.225)\end{array}$ & $\begin{array}{l}-0.043 \\
(-0.325)\end{array}$ & $\begin{array}{l}-0.030 \\
(-0.240)\end{array}$ & $\begin{array}{c}-0.026 \\
(-0.207)\end{array}$ & $\begin{array}{l}-0.022 \\
(-0.170)\end{array}$ \\
\hline Log_AT & $\begin{array}{c}0.077 * * * \\
(3.271)\end{array}$ & $\begin{array}{c}0.072 * * * \\
(3.091)\end{array}$ & $\begin{array}{c}0.072 * * * \\
(3.107)\end{array}$ & $\begin{array}{c}0.073 * * * \\
(3.124)\end{array}$ & $\begin{array}{c}0.006 \\
(0.114)\end{array}$ & $\begin{array}{c}0.003 \\
(0.068)\end{array}$ & $\begin{array}{c}0.003 \\
(0.052)\end{array}$ & $\begin{array}{c}0.003 \\
(0.055)\end{array}$ \\
\hline Log_REVT & $\begin{array}{c}0.033 \\
(1.571)\end{array}$ & $\begin{array}{c}0.023 \\
(1.161)\end{array}$ & $\begin{array}{c}0.024 \\
(1.163)\end{array}$ & $\begin{array}{c}0.023 \\
(1.133)\end{array}$ & $\begin{array}{c}0.145 * * * \\
(3.525)\end{array}$ & $\begin{array}{c}0.130 * * * \\
(3.289)\end{array}$ & $\begin{array}{c}0.132 * * * \\
(3.323)\end{array}$ & $\begin{array}{c}0.132 * * * \\
(3.301)\end{array}$ \\
\hline ROA & $\begin{array}{c}0.044 \\
(1.054)\end{array}$ & $\begin{array}{c}0.037 \\
(0.870)\end{array}$ & $\begin{array}{c}0.041 \\
(0.928)\end{array}$ & $\begin{array}{c}0.039 \\
(0.885)\end{array}$ & $\begin{array}{c}0.018 \\
(0.411)\end{array}$ & $\begin{array}{c}0.004 \\
(0.078)\end{array}$ & $\begin{array}{c}0.009 \\
(0.197)\end{array}$ & $\begin{array}{c}0.011 \\
(0.228)\end{array}$ \\
\hline RDAD_Exp & $\begin{array}{l}-0.178 \\
(-1.348)\end{array}$ & $\begin{array}{l}-0.214 \\
(-1.586)\end{array}$ & $\begin{array}{l}-0.222 * \\
(-1.703)\end{array}$ & $\begin{array}{l}-0.229 * \\
(-1.748)\end{array}$ & $\begin{array}{c}0.156 \\
(0.657)\end{array}$ & $\begin{array}{c}0.090 \\
(0.371)\end{array}$ & $\begin{array}{c}0.078 \\
(0.321)\end{array}$ & $\begin{array}{c}0.085 \\
(0.349)\end{array}$ \\
\hline New_FIN & $\begin{array}{c}-0.024 \\
(-0.374)\end{array}$ & $\begin{array}{c}-0.057 \\
(-0.910)\end{array}$ & $\begin{array}{l}-0.055 \\
(-0.875)\end{array}$ & $\begin{array}{l}-0.060 \\
(-0.969)\end{array}$ & $\begin{array}{l}0.157 * * \\
(2.070)\end{array}$ & $\begin{array}{c}0.113 \\
(1.572)\end{array}$ & $\begin{array}{c}0.115 \\
(1.600)\end{array}$ & $\begin{array}{c}0.119 \\
(1.659)\end{array}$ \\
\hline Big4 & $\begin{array}{c}0.162 * * * \\
(2.738)\end{array}$ & $\begin{array}{c}0.145^{* *} \\
(2.442)\end{array}$ & $\begin{array}{l}0.141 * * \\
(2.358)\end{array}$ & $\begin{array}{l}0.140 * * \\
(2.299)\end{array}$ & $\begin{array}{c}0.108 \\
(1.233)\end{array}$ & $\begin{array}{c}0.097 \\
(1.112)\end{array}$ & $\begin{array}{c}0.088 \\
(0.998)\end{array}$ & $\begin{array}{c}0.088 \\
(1.012)\end{array}$ \\
\hline $\mathrm{VC}$ & $\begin{array}{c}0.284 * * * \\
(3.744)\end{array}$ & $\begin{array}{c}0.229 * * * \\
(3.173)\end{array}$ & $\begin{array}{c}0.233 * * * \\
(3.245)\end{array}$ & $\begin{array}{c}0.235 * * * \\
(3.268)\end{array}$ & $\begin{array}{c}0.529 * * * \\
(4.220)\end{array}$ & $\begin{array}{c}0.468 * * * \\
(3.498)\end{array}$ & $\begin{array}{c}0.473 * * * \\
(3.545)\end{array}$ & $\begin{array}{c}0.472 * * * \\
(3.465)\end{array}$ \\
\hline TopUW & $\begin{array}{c}0.194 * * * \\
(3.769)\end{array}$ & $\begin{array}{c}0.175 * * * \\
(3.653)\end{array}$ & $\begin{array}{c}0.175^{* * *} \\
(3.665)\end{array}$ & $\begin{array}{c}0.174 * * * \\
(3.619)\end{array}$ & $\begin{array}{c}0.102 \\
(1.254)\end{array}$ & $\begin{array}{c}0.084 \\
(1.080)\end{array}$ & $\begin{array}{c}0.085 \\
(1.090)\end{array}$ & $\begin{array}{c}0.086 \\
(1.091)\end{array}$ \\
\hline NasdaqRET_90 & $\begin{array}{c}-0.345 \\
(-0.956)\end{array}$ & $\begin{array}{c}-0.369 \\
(-1.022)\end{array}$ & $\begin{array}{c}-0.366 \\
(-1.012)\end{array}$ & $\begin{array}{c}-0.389 \\
(-1.071)\end{array}$ & $\begin{array}{c}0.585 \\
(1.331)\end{array}$ & $\begin{array}{c}0.557 \\
(1.273)\end{array}$ & $\begin{array}{c}0.561 \\
(1.281)\end{array}$ & $\begin{array}{c}0.594 \\
(1.331)\end{array}$ \\
\hline IPOCount_90 & -0.001 & -0.001 & -0.001 & -0.001 & $0.003^{*}$ & $0.003^{*}$ & $0.003^{*}$ & $0.004 *$ \\
\hline
\end{tabular}




\begin{tabular}{|c|c|c|c|c|c|c|c|c|}
\hline Log_Age & $\begin{array}{c}(-0.251) \\
-0.114 * * * \\
(-3.066)\end{array}$ & $\begin{array}{c}(-0.399) \\
-0.115^{* * *} \\
(-3.152)\end{array}$ & $\begin{array}{c}(-0.361) \\
-0.116^{* * *} \\
(-3.166)\end{array}$ & $\begin{array}{c}(-0.538) \\
-0.114 * * * \\
(-3.190)\end{array}$ & $\begin{array}{c}(1.886) \\
-0.009 \\
(-0.128)\end{array}$ & $\begin{array}{c}(1.749) \\
-0.007 \\
(-0.096)\end{array}$ & $\begin{array}{c}(1.881) \\
-0.008 \\
(-0.116)\end{array}$ & $\begin{array}{c}(1.912) \\
-0.007 \\
(-0.104)\end{array}$ \\
\hline Fixed Effects & $\begin{array}{c}\text { Sector, } \\
\text { Year, } \\
\text { Exchange }\end{array}$ & $\begin{array}{c}\text { Sector, } \\
\text { Year, } \\
\text { Exchange }\end{array}$ & $\begin{array}{c}\text { Sector, } \\
\text { Year, } \\
\text { Exchange }\end{array}$ & $\begin{array}{c}\text { Sector, } \\
\text { Year, } \\
\text { Exchange }\end{array}$ & $\begin{array}{c}\text { Sector, } \\
\text { Year, } \\
\text { Exchange }\end{array}$ & $\begin{array}{l}\text { Sector, } \\
\text { Year, } \\
\text { Exchange }\end{array}$ & $\begin{array}{c}\text { Sector, } \\
\text { Year, } \\
\text { Exchange }\end{array}$ & $\begin{array}{c}\text { Sector, } \\
\text { Year, } \\
\text { Exchange }\end{array}$ \\
\hline Observations & 569 & 569 & 569 & 569 & 569 & 569 & 569 & 569 \\
\hline $\begin{array}{l}\text { Log-Likelihood / } \\
\text { Adjusted } \mathrm{R}^{2}\end{array}$ & -1432 & -1423 & -1422 & -1421 & 0.360 & 0.372 & 0.373 & 0.374 \\
\hline \multicolumn{9}{|c|}{ Panel B: Entropy-balanced models } \\
\hline IConf & $\begin{array}{l}0.155^{*} \\
(1.909)\end{array}$ & & & & $\begin{array}{c}0.297 * * * \\
(3.901)\end{array}$ & & & \\
\hline Log_PR & & $\begin{array}{c}0.113 * * * \\
(4.829)\end{array}$ & $\begin{array}{c}0.142 * * * \\
(5.185)\end{array}$ & & & $\begin{array}{c}0.187 * * * \\
(3.419)\end{array}$ & $\begin{array}{c}0.136 * * \\
(2.474)\end{array}$ & \\
\hline PreSOR*Log_PR & & & $\begin{array}{c}-0.115^{* *} \\
(-2.668)\end{array}$ & & & & $\begin{array}{c}0.218^{* *} \\
(2.573)\end{array}$ & \\
\hline $\begin{array}{l}\text { Additional Controls } \\
\text { Included? }\end{array}$ & Yes & Yes & Yes & & Yes & Yes & Yes & \\
\hline Fixed effects & $\begin{array}{l}\text { Sector, } \\
\text { Year, } \\
\text { Exchange }\end{array}$ & $\begin{array}{l}\text { Sector, } \\
\text { Year, } \\
\text { Exchange }\end{array}$ & $\begin{array}{l}\text { Sector, } \\
\text { Year, } \\
\text { Exchange }\end{array}$ & & $\begin{array}{l}\text { Sector, } \\
\text { Year, } \\
\text { Exchange }\end{array}$ & $\begin{array}{l}\text { Sector, } \\
\text { Year, } \\
\text { Exchange }\end{array}$ & $\begin{array}{c}\text { Sector, } \\
\text { Year, } \\
\text { Exchange }\end{array}$ & \\
\hline Observations & 569 & 569 & 569 & & 569 & 569 & 569 & \\
\hline
\end{tabular}


Table 8

Information asymmetry, price volatility, and pre-prospectus disclosure

Results for models explaining measures of post-IPO information asymmetry and price volatility during the 24-day quiet period following the start of IPO trading (excluding the offering date). During this period, firms' disclosures are largely limited to disclosures of regulated information (such as earnings announcements). The average daily bid-ask spread is calculated using closing prices available on CRSP (BASpread_IM) and post-IPO equity volatility is the standard deviation of daily abnormal returns measured as the firm's daily return minus the daily return to the firm's Fama-French 5 x 5 size and B/M portfolio (STD_ARETIM). Results in Panel A (B) are based on OLS (weighted ordinary least squares models where weights are specified for the control sample of observations using entropy balancing; see Table B.2 of Appendix B for evidence of covariate balance after applying entropy balancing). The independent variables of interest are an indicator variable for whether the firm attends an investor conference (IConf) and the natural $\log$ of the number of press releases issued $\left(\log _{-} P R\right)$ by the firm in the 12-month period prior to the filing of its IPO prospectus. All models include IPO-level controls (see Eq. [1] in the text) along with indicators for the primary sector in which the IPO firm operates, the year of the offering, and the exchange on which the IPO is listed (indicators suppressed for presentation). Standard errors clustered by calendar quarter are presented in parentheses below the coefficients. *, **, and *** denote two-tailed pvalues significant at a $10 \%, 5 \%$, and $1 \%$ level, respectively. See Appendix A for detailed variable definitions.

\begin{tabular}{|c|c|c|c|c|c|c|c|c|}
\hline \multirow{2}{*}{$\begin{array}{l}\text { Dep. Variable } \\
\text { Model }\end{array}$} & \multicolumn{4}{|c|}{ STD_ARET1M } & \multicolumn{4}{|c|}{ BASpread_1M } \\
\hline & (1) & (2) & (3) & (4) & (5) & (6) & (7) & (8) \\
\hline \multicolumn{9}{|l|}{ Panel A: OLS models } \\
\hline \multirow[t]{2}{*}{ IConf } & 0.003 & & 0.003 & 0.003 & -0.028 & & -0.012 & -0.009 \\
\hline & $(1.328)$ & & (1.133) & $(0.979)$ & $(-0.420)$ & & $(-0.168)$ & $(-0.125)$ \\
\hline \multirow[t]{2}{*}{ Log_PR } & & 0.001 & 0.001 & 0.002 & & -0.030 & -0.029 & -0.035 \\
\hline & & (1.263) & $(0.953)$ & (1.677) & & $(-1.098)$ & $(-1.006)$ & $(-1.027)$ \\
\hline PreSOR*Log_PR & & & & $\begin{array}{c}-0.003 * * \\
(-2.421)\end{array}$ & & & & $\begin{array}{c}0.022 \\
(0.522)\end{array}$ \\
\hline \multirow[t]{2}{*}{ ProdMktFluid } & -0.000 & -0.000 & -0.000 & -0.000 & 0.012 & 0.013 & 0.013 & 0.013 \\
\hline & $(-0.880)$ & $(-0.858)$ & $(-0.969)$ & $(-0.889)$ & $(0.888)$ & $(0.952)$ & (0.954) & $(0.939)$ \\
\hline \multirow[t]{2}{*}{ DualClass } & 0.000 & 0.000 & 0.000 & 0.000 & 0.035 & 0.032 & 0.032 & 0.033 \\
\hline & $(0.111)$ & $(0.121)$ & $(0.165)$ & $(0.075)$ & $(0.441)$ & $(0.392)$ & $(0.388)$ & $(0.405)$ \\
\hline \multirow[t]{2}{*}{ Log_AT } & $-0.002 * *$ & $-0.002 * *$ & $-0.002 * *$ & $-0.002 * *$ & $-0.122 * * *$ & $-0.121 * * *$ & $-0.121 * * *$ & $-0.121 * * *$ \\
\hline & $(-2.357)$ & $(-2.368)$ & $(-2.389)$ & $(-2.401)$ & $(-5.167)$ & $(-4.975)$ & $(-4.990)$ & $(-5.012)$ \\
\hline \multirow[t]{2}{*}{ Log_REVT } & 0.001 & 0.001 & 0.001 & 0.001 & -0.015 & -0.012 & -0.013 & -0.012 \\
\hline & $(1.420)$ & (1.298) & (1.345) & (1.309) & $(-0.906)$ & $(-0.720)$ & $(-0.733)$ & $(-0.716)$ \\
\hline \multirow{2}{*}{ ROA } & -0.001 & -0.001 & -0.001 & -0.001 & 0.032 & 0.033 & 0.033 & 0.034 \\
\hline & $(-0.338)$ & $(-0.407)$ & $(-0.349)$ & $(-0.399)$ & $(0.597)$ & (0.619) & (0.614) & $(0.630)$ \\
\hline \multirow[t]{2}{*}{ RDAD_Exp } & 0.007 & 0.007 & 0.007 & 0.007 & 0.120 & 0.132 & 0.133 & 0.135 \\
\hline & $(1.629)$ & $(1.551)$ & (1.503) & $(1.396)$ & $(0.706)$ & $(0.777)$ & $(0.782)$ & $(0.796)$ \\
\hline \multirow[t]{2}{*}{ New_FIN } & $0.007 * *$ & $0.006 * *$ & $0.006 * *$ & $0.006 * *$ & 0.049 & 0.057 & 0.057 & 0.058 \\
\hline & $(2.247)$ & (2.186) & (2.194) & (2.149) & $(0.734)$ & (0.834) & $(0.830)$ & $(0.844)$ \\
\hline \multirow[t]{2}{*}{ Big4 } & $-0.005 * *$ & $-0.005 * *$ & $-0.005 * *$ & $-0.005 * *$ & $-0.296 * * *$ & $-0.292 * * *$ & $-0.292 * * *$ & $-0.292 * * *$ \\
\hline & $(-2.176)$ & $(-2.117)$ & $(-2.271)$ & $(-2.240)$ & $(-3.871)$ & $(-3.909)$ & $(-3.891)$ & $(-3.877)$ \\
\hline \multirow[t]{2}{*}{$\mathrm{VC}$} & 0.002 & 0.001 & 0.001 & 0.001 & -0.079 & -0.066 & -0.066 & -0.067 \\
\hline & $(0.952)$ & $(0.725)$ & $(0.767)$ & $(0.813)$ & $(-1.123)$ & $(-0.908)$ & $(-0.904)$ & $(-0.907)$ \\
\hline \multirow[t]{2}{*}{ TopUW } & 0.001 & 0.001 & 0.001 & 0.001 & -0.073 & -0.069 & -0.070 & -0.069 \\
\hline & $(0.917)$ & $(0.797)$ & $(0.830)$ & $(0.855)$ & $(-1.548)$ & $(-1.488)$ & $(-1.488)$ & $(-1.484)$ \\
\hline \multirow[t]{2}{*}{ NasdaqRET_90 } & 0.004 & 0.004 & 0.004 & 0.003 & $-1.015 * * *$ & $-1.008 * * *$ & $-1.009 * * *$ & $-1.001 * * *$ \\
\hline & $(0.547)$ & $(0.505)$ & $(0.520)$ & $(0.358)$ & $(-2.919)$ & $(-2.888)$ & $(-2.878)$ & $(-2.810)$ \\
\hline \multirow[t]{2}{*}{ IPOCount_90 } & -0.000 & -0.000 & -0.000 & -0.000 & -0.000 & -0.000 & -0.000 & -0.000 \\
\hline & $(-0.805)$ & $(-0.912)$ & $(-0.847)$ & $(-1.201)$ & $(-0.061)$ & $(-0.044)$ & $(-0.048)$ & $(-0.025)$ \\
\hline \multirow[t]{2}{*}{ Log_Age } & -0.001 & -0.001 & -0.001 & -0.001 & 0.014 & 0.014 & 0.014 & 0.014 \\
\hline & $(-1.501)$ & $(-1.493)$ & $(-1.496)$ & $(-1.564)$ & $(0.446)$ & $(0.445)$ & $(0.448)$ & $(0.453)$ \\
\hline
\end{tabular}




\begin{tabular}{|c|c|c|c|c|c|c|c|c|}
\hline Fixed Effects & $\begin{array}{l}\text { Sector, } \\
\text { Year, } \\
\text { Exchange }\end{array}$ & $\begin{array}{l}\text { Sector, } \\
\text { Year, } \\
\text { Exchange }\end{array}$ & $\begin{array}{l}\text { Sector, } \\
\text { Year, } \\
\text { Exchange }\end{array}$ & $\begin{array}{l}\text { Sector, } \\
\text { Year, } \\
\text { Exchange }\end{array}$ & $\begin{array}{l}\text { Sector, } \\
\text { Year, } \\
\text { Exchange }\end{array}$ & $\begin{array}{l}\text { Sector, } \\
\text { Year, } \\
\text { Exchange }\end{array}$ & $\begin{array}{l}\text { Sector, } \\
\text { Year, } \\
\text { Exchange }\end{array}$ & $\begin{array}{l}\text { Sector, } \\
\text { Year, } \\
\text { Exchange }\end{array}$ \\
\hline Observations & 569 & 569 & 569 & 569 & 569 & 569 & 569 & 569 \\
\hline Adjusted $\mathrm{R}^{2}$ & 0.159 & 0.157 & 0.159 & 0.164 & 0.350 & 0.351 & 0.350 & 0.349 \\
\hline \multicolumn{9}{|c|}{ Panel B: Entropy-balanced models } \\
\hline IConf & $\begin{array}{c}0.002 \\
(0.827)\end{array}$ & & & & $\begin{array}{c}0.099 \\
(1.548)\end{array}$ & & & \\
\hline Log_PR & & $\begin{array}{c}-0.001 \\
(-0.624)\end{array}$ & $\begin{array}{c}-0.001 \\
(-0.509)\end{array}$ & & & $\begin{array}{c}0.015 \\
(0.484)\end{array}$ & $\begin{array}{c}0.008 \\
(0.228)\end{array}$ & \\
\hline PreSOR*Log_PR & & & $\begin{array}{c}0.000 \\
(0.059)\end{array}$ & & & & $\begin{array}{c}0.026 \\
(0.549)\end{array}$ & \\
\hline Additional Controls & Yes & Yes & Yes & & Yes & Yes & Yes & \\
\hline Fixed effects & $\begin{array}{c}\text { Sector, } \\
\text { Year, } \\
\text { Exchange }\end{array}$ & $\begin{array}{l}\text { Sector, } \\
\text { Year, } \\
\text { Exchange }\end{array}$ & $\begin{array}{l}\text { Sector, } \\
\text { Year, } \\
\text { Exchange }\end{array}$ & & $\begin{array}{c}\text { Sector, } \\
\text { Year, } \\
\text { Exchange }\end{array}$ & $\begin{array}{c}\text { Sector, } \\
\text { Year, } \\
\text { Exchange }\end{array}$ & $\begin{array}{l}\text { Sector, } \\
\text { Year, } \\
\text { Exchange }\end{array}$ & \\
\hline Observations & 569 & 569 & 569 & & 569 & 569 & 569 & \\
\hline
\end{tabular}




\section{Table 9}

\section{Incentives for IPO managers}

Results for models explaining measures of the proportion of the firm's equity ownership that is retained (rather than sold) in the IPO (Retain) and for the rank of the wealth revaluation difference (Wealth_Diff) that pre-IPO shareholders experience which is measured as the difference between money-left-on-the-table as a result of first-day underpricing (in \$millions) and the wealth revaluation on secondary shares as a result of filing price revisions plus the change from the filing price to the first-day closing price on shares retained by the firm (which follows the approach by Loughran and Ritter, 2002). Results in Panel A (B) are based on OLS (weighted ordinary least squares models where weights are specified for the control sample of observations using entropy balancing; see Table B.2 of Appendix B for evidence of covariate balance after applying entropy balancing). The independent variables of interest are an indicator variable for whether the firm attends an investor conference (IConf) and the natural log of the number of press releases issued $\left(\log _{-} P R\right)$ by the firm in the 12-month period prior to the filing of its IPO prospectus. All models include IPO-level controls (see Eq. [1] in the text) along with indicators for the primary sector in which the IPO firm operates, the year of the offering, and the exchange on which the IPO is listed (indicators suppressed for presentation). Standard errors clustered by calendar quarter are presented in parentheses below the coefficients. *, **, and *** denote two-tailed p-values significant at a 10\%, 5\%, and $1 \%$ level, respectively. See Appendix A for detailed variable definitions.

\begin{tabular}{|c|c|c|c|c|c|c|c|c|}
\hline \multirow{2}{*}{$\begin{array}{l}\text { Dep. Variable } \\
\text { Model }\end{array}$} & \multicolumn{4}{|c|}{ Retain } & \multicolumn{4}{|c|}{ Wealth_Diff (Rank) } \\
\hline & (1) & (2) & (3) & (4) & $(5)$ & (6) & (7) & $(8)$ \\
\hline \multicolumn{9}{|l|}{ Panel A: OLS models } \\
\hline \multirow[t]{2}{*}{ IConf } & 0.013 & & 0.011 & 0.010 & $0.098^{* *}$ & & $0.076^{*}$ & 0.068 \\
\hline & $(0.986)$ & & $(0.774)$ & $(0.733)$ & $(2.244)$ & & $(1.720)$ & $(1.575)$ \\
\hline \multirow[t]{2}{*}{ Log_PR } & & 0.005 & 0.004 & 0.005 & & $0.047 * * *$ & $0.040 * *$ & $0.056^{* * *}$ \\
\hline & & $(0.966)$ & $(0.735)$ & $(1.050)$ & & (3.037) & $(2.616)$ & $(3.141)$ \\
\hline PreSOR*Log_PR & & & & $\begin{array}{c}-0.006 \\
(-0.335)\end{array}$ & & & & $\begin{array}{r}-0.056 * * \\
(-2.109)\end{array}$ \\
\hline ProdMktFluid & $\begin{array}{c}0.003 \\
(1.213)\end{array}$ & $\begin{array}{c}0.003 \\
(1.195)\end{array}$ & $\begin{array}{c}0.003 \\
(1.151)\end{array}$ & $\begin{array}{c}0.003 \\
(1.148)\end{array}$ & $\begin{array}{c}-0.013 * * * \\
(-2.781)\end{array}$ & $\begin{array}{c}-0.013 * * * \\
(-2.772)\end{array}$ & $\begin{array}{c}-0.014 * * * \\
(-2.952)\end{array}$ & $\begin{array}{c}-0.013 * * * \\
(-2.821)\end{array}$ \\
\hline DualClass & $\begin{array}{c}-0.044 \\
(-1.158)\end{array}$ & $\begin{array}{l}-0.044 \\
(-1.148)\end{array}$ & $\begin{array}{l}-0.044 \\
(-1.140)\end{array}$ & $\begin{array}{c}-0.044 \\
(-1.146)\end{array}$ & $\begin{array}{c}0.033 \\
(0.553)\end{array}$ & $\begin{array}{c}0.036 \\
(0.621)\end{array}$ & $\begin{array}{c}0.038 \\
(0.652)\end{array}$ & $\begin{array}{c}0.035 \\
(0.611)\end{array}$ \\
\hline Log_AT & $\begin{array}{c}0.022 * * * \\
(3.631)\end{array}$ & $\begin{array}{c}0.022 * * * \\
(3.566)\end{array}$ & $\begin{array}{c}0.022 * * * \\
(3.557)\end{array}$ & $\begin{array}{c}0.022 * * * * \\
(3.561)\end{array}$ & $\begin{array}{l}-0.000 \\
(-0.025)\end{array}$ & $\begin{array}{l}-0.002 \\
(-0.150)\end{array}$ & $\begin{array}{c}-0.002 \\
(-0.183)\end{array}$ & $\begin{array}{l}-0.002 \\
(-0.131)\end{array}$ \\
\hline Log_REVT & $\begin{array}{l}0.013^{*} \\
(1.840)\end{array}$ & $\begin{array}{l}0.013^{*} \\
(1.793)\end{array}$ & $\begin{array}{l}0.013^{*} \\
(1.825)\end{array}$ & $\begin{array}{l}0.013^{*} \\
(1.817)\end{array}$ & $\begin{array}{l}0.017 \\
(1.493)\end{array}$ & $\begin{array}{c}0.013 \\
(1.186)\end{array}$ & $\begin{array}{c}0.014 \\
(1.303)\end{array}$ & $\begin{array}{c}0.014 \\
(1.257)\end{array}$ \\
\hline ROA & $\begin{array}{c}-0.001 \\
(-0.105)\end{array}$ & $\begin{array}{c}-0.001 \\
(-0.165)\end{array}$ & $\begin{array}{l}-0.001 \\
(-0.117)\end{array}$ & $\begin{array}{c}-0.001 \\
(-0.138)\end{array}$ & $\begin{array}{c}0.017 \\
(1.340)\end{array}$ & $\begin{array}{c}0.013 \\
(1.012)\end{array}$ & $\begin{array}{l}0.016 \\
(1.257)\end{array}$ & $\begin{array}{c}0.014 \\
(1.110)\end{array}$ \\
\hline RDAD_Exp & $\begin{array}{c}0.022 \\
(0.651)\end{array}$ & $\begin{array}{c}0.021 \\
(0.639)\end{array}$ & $\begin{array}{c}0.020 \\
(0.604)\end{array}$ & $\begin{array}{c}0.020 \\
(0.579)\end{array}$ & $\begin{array}{l}-0.011 \\
(-0.148)\end{array}$ & $\begin{array}{l}-0.021 \\
(-0.289)\end{array}$ & $\begin{array}{c}-0.028 \\
(-0.391)\end{array}$ & $\begin{array}{c}-0.034 \\
(-0.493)\end{array}$ \\
\hline New_FIN & $\begin{array}{l}0.024^{*} \\
(1.734)\end{array}$ & $\begin{array}{c}0.022 \\
(1.676)\end{array}$ & $\begin{array}{l}0.023^{*} \\
(1.694)\end{array}$ & $\begin{array}{c}0.022 \\
(1.646)\end{array}$ & $\begin{array}{l}-0.013 \\
(-0.656)\end{array}$ & $\begin{array}{c}-0.024 \\
(-1.072)\end{array}$ & $\begin{array}{c}-0.022 \\
(-1.064)\end{array}$ & $\begin{array}{c}-0.026 \\
(-1.228)\end{array}$ \\
\hline Big4 & $\begin{array}{c}-0.038 * * \\
(-2.233)\end{array}$ & $\begin{array}{c}-0.038 * * \\
(-2.227)\end{array}$ & $\begin{array}{c}-0.038 * * \\
(-2.290)\end{array}$ & $\begin{array}{c}-0.039 * * \\
(-2.285)\end{array}$ & $\begin{array}{c}-0.031 \\
(-0.832)\end{array}$ & $\begin{array}{c}-0.033 \\
(-0.878)\end{array}$ & $\begin{array}{c}-0.037 \\
(-0.993)\end{array}$ & $\begin{array}{c}-0.037 \\
(-0.980)\end{array}$ \\
\hline $\mathrm{VC}$ & $\begin{array}{c}0.084 * * * \\
(5.110)\end{array}$ & $\begin{array}{c}0.082 * * * \\
(4.901)\end{array}$ & $\begin{array}{c}0.083 * * * \\
(4.930)\end{array}$ & $\begin{array}{c}0.083 * * * \\
(4.997)\end{array}$ & $\begin{array}{c}0.045 \\
(1.303)\end{array}$ & $\begin{array}{c}0.026 \\
(0.716)\end{array}$ & $\begin{array}{c}0.029 \\
(0.788)\end{array}$ & $\begin{array}{c}0.030 \\
(0.853)\end{array}$ \\
\hline TopUW & $\begin{array}{c}0.032 * * * \\
(3.082)\end{array}$ & $\begin{array}{c}0.031 * * * \\
(3.003)\end{array}$ & $\begin{array}{c}0.032 * * * \\
(3.014)\end{array}$ & $\begin{array}{c}0.032 * * * \\
(3.000)\end{array}$ & $\begin{array}{c}0.097 * * * \\
(3.216)\end{array}$ & $\begin{array}{c}0.092 * * * \\
(3.128)\end{array}$ & $\begin{array}{c}0.093 * * * \\
(3.178)\end{array}$ & $\begin{array}{c}0.092 * * * \\
(3.235)\end{array}$ \\
\hline NasdaqRET_90 & $\begin{array}{c}-0.170 * * \\
(-2.374)\end{array}$ & $\begin{array}{c}-0.171 * * \\
(-2.411)\end{array}$ & $\begin{array}{c}-0.171 * * \\
(-2.384)\end{array}$ & $\begin{array}{c}-0.173 * * \\
(-2.355)\end{array}$ & $\begin{array}{c}0.726 * * * \\
(3.393)\end{array}$ & $\begin{array}{c}0.715^{* * *} \\
(3.331)\end{array}$ & $\begin{array}{c}0.717 * * * \\
(3.332)\end{array}$ & $\begin{array}{c}0.698 * * * \\
(3.264)\end{array}$ \\
\hline IPOCount_90 & $\begin{array}{c}0.000 \\
(1.305)\end{array}$ & $\begin{array}{c}0.000 \\
(1.261)\end{array}$ & $\begin{array}{c}0.000 \\
(1.283)\end{array}$ & $\begin{array}{c}0.000 \\
(1.123)\end{array}$ & $\begin{array}{c}0.001 \\
(0.736)\end{array}$ & $\begin{array}{c}0.001 \\
(0.597)\end{array}$ & $\begin{array}{c}0.001 \\
(0.701)\end{array}$ & $\begin{array}{c}0.000 \\
(0.496)\end{array}$ \\
\hline Log_Age & $\begin{array}{c}-0.009 \\
(-0.748)\end{array}$ & $\begin{array}{c}-0.009 \\
(-0.743)\end{array}$ & $\begin{array}{c}-0.009 \\
(-0.749)\end{array}$ & $\begin{array}{c}-0.009 \\
(-0.752)\end{array}$ & $\begin{array}{c}-0.017 \\
(-0.863)\end{array}$ & $\begin{array}{c}-0.017 \\
(-0.821)\end{array}$ & $\begin{array}{c}-0.018 \\
(-0.866)\end{array}$ & $\begin{array}{c}-0.018 \\
(-0.919)\end{array}$ \\
\hline
\end{tabular}




\begin{tabular}{|c|c|c|c|c|c|c|c|c|}
\hline Additional Controls & Yes & Yes & Yes & Yes & Yes & Yes & Yes & Yes \\
\hline Fixed Effects & $\begin{array}{l}\text { Sector, } \\
\text { Year, } \\
\text { Exchange }\end{array}$ & $\begin{array}{l}\text { Sector, } \\
\text { Year, } \\
\text { Exchange }\end{array}$ & $\begin{array}{l}\text { Sector, } \\
\text { Year, } \\
\text { Exchange }\end{array}$ & $\begin{array}{l}\text { Sector, } \\
\text { Year, } \\
\text { Exchange }\end{array}$ & $\begin{array}{l}\text { Sector, } \\
\text { Year, } \\
\text { Exchange }\end{array}$ & $\begin{array}{c}\text { Sector, } \\
\text { Year, } \\
\text { Exchange }\end{array}$ & $\begin{array}{l}\text { Sector, } \\
\text { Year, } \\
\text { Exchange }\end{array}$ & $\begin{array}{c}\text { Sector, } \\
\text { Year, } \\
\text { Exchange }\end{array}$ \\
\hline Observations & 569 & 569 & 569 & 569 & 569 & 569 & 569 & 569 \\
\hline Adjusted $\mathrm{R}^{2}$ & 0.353 & 0.353 & 0.352 & 0.351 & 0.192 & 0.197 & 0.202 & 0.207 \\
\hline \multicolumn{9}{|c|}{ Panel B: Entropy-balanced models } \\
\hline IConf & $\begin{array}{c}0.025^{* *} \\
(2.212)\end{array}$ & & & & $\begin{array}{c}0.084 * * * \\
(2.790)\end{array}$ & & & \\
\hline Log_PR & & $\begin{array}{c}0.002 \\
(0.353)\end{array}$ & $\begin{array}{c}0.001 \\
(0.229)\end{array}$ & & & $\begin{array}{c}0.042^{* * *} \\
(2.561)\end{array}$ & $\begin{array}{c}0.056^{* * *} \\
(3.310)\end{array}$ & \\
\hline PreSOR*Log_PR & & & $\begin{array}{c}0.002 \\
(0.214)\end{array}$ & & & & $\begin{array}{l}-0.055^{*} \\
(-1.834)\end{array}$ & \\
\hline $\begin{array}{l}\text { Additional Controls } \\
\text { Included? }\end{array}$ & Yes & Yes & Yes & & Yes & Yes & Yes & \\
\hline Fixed effects & $\begin{array}{l}\text { Sector, } \\
\text { Year, } \\
\text { Exchange }\end{array}$ & $\begin{array}{l}\text { Sector, } \\
\text { Year, } \\
\text { Exchange }\end{array}$ & $\begin{array}{l}\text { Sector, } \\
\text { Year, } \\
\text { Exchange }\end{array}$ & & $\begin{array}{l}\text { Sector, } \\
\text { Year, } \\
\text { Exchange }\end{array}$ & $\begin{array}{l}\text { Sector, } \\
\text { Year, } \\
\text { Exchange }\end{array}$ & $\begin{array}{l}\text { Sector, } \\
\text { Year, } \\
\text { Exchange }\end{array}$ & \\
\hline Observations & 569 & 569 & 569 & & 569 & 569 & 569 & \\
\hline
\end{tabular}

